\title{
Retail Investor Attention and IPO Valuation
}

\author{
Hugh M. J. Colaco \\ Aston Business School \\ Birmingham B4 7ET \\ United Kingdom \\ +44 (0)1212043193 \\ h.colaco@aston.ac.uk \\ Amedeo De Cesari \\ Alliance Manchester Business School \\ Manchester M15 6PB \\ United Kingdom \\ +44 (0)161306 6403 \\ amedeo.decesari@mbs.ac.uk \\ Shantaram P. Hegde \\ University of Connecticut \\ Storrs, CT 06269, USA \\ +18604865135 \\ shegde@business.uconn.edu
}

November 7, 2016

\begin{abstract}
Given restrictions placed on communication with prospective investors, retail investor attention can help firms/underwriters with the task of initially valuing an IPO. Using Google search volume to proxy for retail investor attention, we find that the presence of and an increase in retail attention following initial filing but prior to initial pricing are positively related to initial valuations. Our results are robust to alternative matching methods to identify our matched sample of non-IPO firms and to including several controls for institutional demand. We conclude that retail investor attention plays a critical role in the early stages of IPO valuation.
\end{abstract}

Keywords: initial public offering; equity valuation; retail investor; investor attention

JEL Classification: G30; G32

We thank three anonymous referees, John Doukas (the Editor), Tim Jenkinson, Robert Kieschnick, Jay Ritter, and seminar participants at the 2013 European Financial Management Association (University of Reading, UK), 2013 Financial Management Association (Chicago, USA), 2013 India Finance Conference (Indian Institute of Management, Ahmedabad, India), and 2014 Behavioral Finance Working Group (Queen Mary University of London, UK) annual meetings for useful comments. 


\section{Introduction}

IPO valuation is challenging because of limited firm history and lack of presence in the capital markets. While the offer price has the advantage of reflecting institutional demand for the IPO, the initial valuation is at a significant disadvantage since the roadshow typically occurs later. ${ }^{1}$ Moreover, restrictions are placed on communication between issuers/underwriters and prospective (mostly institutional) investors prior to setting the initial price range. In this environment, firms and underwriters may be dependent on other sources of information to initially value an IPO. ${ }^{2}$ Retail investor attention, a precursor of retail demand for shares, may be one such source. For example, Demos and Dembosky (2012) report that unusually strong demand from retail investors was one factor influencing the upward valuation of Facebook, Inc.'s IPO price in 2012. The objective of this paper is to examine the influence of retail investor attention on initial IPO valuation.

The importance of initial valuation to firms and underwriters is highlighted in Hanley and Hoberg (2010, p. 2826), who argue that significant resources are expended by a firm and its underwriters and legal counsel to acquire information about the IPO, which results in more precise initial valuation relative to the final valuation; as a result, the firm's dependence on bookbuilding is reduced. The implication in Hanley

\footnotetext{
${ }^{1}$ The initial valuation typically occurs in the form of a price range. The midpoint of the initial price range (i.e., average of high and low prices) is used as an unbiased estimator of final valuation (offer price) by many studies, including Hanley (1993), Loughran and Ritter (2002), and Bradley and Jordan (2002). However, Lowry and Schwert (2004) find that public information is not fully incorporated into the initial price range although the economic significance is small. Many studies focus on valuation based on the offer price (e.g., Purnanandam and Swaminathan, 2004; Houston et al., 2006).

${ }^{2}$ Given that valuing an IPO is an inherently complex activity that is more of an art than a science, underwriters generally rely on a wide set of variables to assess market conditions and investor demand for an issue (McCarthy, 1999). For instance, Internet IPOs are sometimes valued using criteria such as web traffic, number of page views per user, and number of engaged shoppers (Rueda, 2001).
} 
and Hoberg (2010) is that institutional interest is not available before the filing of the initial price range. Furthermore, Kim and Ritter (1999, p. 411) posit that accounting information and comparable firm multiples alone are not sufficient to ensure accurate pricing when determining the initial price range. Rather, the market's demand for the IPO helps to improve pricing accuracy.

Prior to the passage of the Jumpstart Our Business Startups (JOBS) Act in 2012 in the United States (US), Section 5 of the Securities Act of 1933 did not allow issuers and underwriters to communicate with investors before the filing of a preliminary registration statement. Moreover, Rule 15c2-8 of the Securities Exchange Act of 1934 imposed restrictions on issuers and underwriters that prevented them from soliciting offers and indications of interest from investors before the filing of a prospectus containing an initial price range (Practical Law, 2014). As a result, US firms and underwriters have been unable to engage in oral and written communication to a significant extent with prospective investors before the initial price range is filed (Latham and Watkins, 2014). Several studies document that institutional investor demand is not officially available when the initial price range is set (Hanley, 1993, pp. 231-32; Ljungqvist and Wilhelm, 2002, p. 178; Wang and Yung, 2011, p. 302; Chuluun, 2015, footnote 7).

In this restricted information environment, retail investor attention may contain valuable clues about latent investor demand for the IPO that could help firms and underwriters initially value an IPO. Retail investors are allocated a reasonably large block of IPO shares. ${ }^{3}$ Furthermore, Barber and Odean (2008) posit that retail attention is important because it may be a precursor of retail demand for shares in the aftermarket. As a result, incorporating retail attention could lead to more appropriate valuations for newly public firms and reduce the need for underwriters to engage in costly price stabilization activities when trading begins (Chowdhry and Nanda, 1996). The attention paid by retail investors to a going-public firm may reflect the intrinsic quality of the firm's IPO and convey genuine information that the firm and its

\footnotetext{
${ }^{3}$ Aggarwal et al. (2002) find that institutional investors are allocated a median of around three-quarters of the shares offered in an IPO, implying that retail investors get the remaining one-quarter. More recently, Demos and Light (2013) state that typically less than a third of IPO shares are set aside for retail investors.
} 
underwriters can use when setting the firm's IPO valuation. At the same time, even if retail attention is caused by investors' behavioral biases, the related irrational retail investor demand could still be taken into account by rational firms and underwriters in the IPO valuation process.

Based on a sample of 185 US IPOs from 2004 to 2007, Da et al. (2011) find a significant upward trend in Google's search volume index (SVI) — a proxy for retail investor attention ${ }^{4}$ - beginning two to three weeks before the IPO week, followed by a significant jump in SVI during the IPO week, indicating an increase in retail attention towards the stock. ${ }^{5}$ The SVI, however, reverts to its pre-IPO level two to three weeks after the IPO, an indication that retail attention is not permanent.

We examine the relationship between retail investor attention (proxied by SVI) and initial IPO valuation as measured by Price-to-Sales, Price-to-Assets, and Price-to-EBITDA. Each of the three valuation measures is captured for an IPO firm relative to that of a matched firm. We are specifically interested in examining how the presence of and change in retail attention following the initial filing (S-1, or equivalent)

\footnotetext{
${ }^{4}$ Using retail order execution from SEC Rule 11Ac1-5 (Dash-5) reports, Da et al. (2011) find a strong link between changes in SVI and retail investor trading. Furthermore, this link is stronger for market centers that attract less sophisticated individual investors. Other recent papers that rely on this proxy of retail attention are Doukas et al. (2016), Dimpfl and Jank (2016), Vozlyublennaia (2014), Bae and Wang (2012), and Drake et al. (2012).

${ }^{5}$ We are not claiming that Google's SVI is the only proxy of retail attention or that this proxy is used by issuers and underwriters and is available to them in a timely way to price an IPO. Retail attention could be estimated in alternative ways, for instance, by using information on informal inquiries from retail customers of the underwriter, on the customer base of the issuer (e.g., number of customers, customer loyalty and satisfaction, wealth of the average customer and likelihood that the average customer trades stock), and on web traffic on the issuer's website. It is likely that Google's SVI is correlated with alternative measures of retail attention that issuers and underwriters may use. If not, we would not be able to report significant findings in our study.
} 
are related to the initial valuation, which is typically presented for the first time in a later amended filing (S-1/A, or equivalent) with the Securities and Exchange Commission (SEC). ${ }^{6}$ The initial filing is typically the very first company document in the public domain and contains information on many aspects of the firm and the proposed offering, including use of proceeds, risk factors, management's discussion and analysis, and recent financial statements. Such comprehensive disclosure should increase attention to the firm prior to the initial valuation.

Examining US IPOs in the period 2004-2011, we find that the presence of and an increase in retail attention are associated with higher initial valuations. Our results are robust to including: i) three matching methods to identify our matched sample (based on several factors: time of the IPO, industry, assets, sales, profit margin, growth opportunities, and net income divided by assets); ii) the low, midpoint, or high of the initial price range as the point estimate for our valuation measures; iii) controls for institutional interest, including media coverage, price update, institutional ownership percentage, and number of institutional investors; iv) controls for promotional efforts of underwriters as captured by the presence of multiple lead underwriters, number of co-managers, underwriter compensation in the form of gross spread, and media coverage; and v) firm-specific controls including textual analysis variables.

Our findings are highly economically significant. For example, in our base regressions, the presence of and the increase in retail investor attention account for around one-third of the standard deviation of Price-to-Sales. Thus, the economic magnitude of our findings is quite large. While our analysis is comprehensive, we cannot entirely rule out the possibility of omitted variables bias. For example, initial valuation could be influenced by informal (albeit illegal) conversations between issuers/underwriters and institutional investors on the golf course, which we obviously cannot capture.

\footnotetext{
${ }^{6}$ To clarify terminology used henceforth, the date on which the initial filing is filed with the SEC is referred to as the "filing date." Similarly, the date on which the initial valuation (or initial pricing) is filed with the SEC is referred to as the "pricing date." By "equivalent," we mean other filing types (e.g., SB-2 and SB-2/A) that satisfy our screening criteria.
} 
Our paper differs from Da et al. (2011) on several fronts. These authors examine the relationship between retail investor attention and underpricing and long-run performance; thus, for these investigators, valuation reflects institutional and overall market demand for the IPO shares, not just underwriters' IPO valuation activities. By contrast, our paper more thoroughly investigates underwriters' efforts to price IPO shares, well before bookbuilding and stock market trading begin, by focusing on the very first publicly disclosed valuation of a company. With a very limited information set, firms and underwriters must arrive at a reasonable initial valuation, albeit in the form of a range. Thus, in our setting, retail attention is critical, as institutional information is not available. Relatedly, in Da et al. (and in many other studies that examine retail investors), retail attention is captured simultaneously with institutional demand. On the other hand, the unique setting in the US allows us to focus on initial valuation and, thereby, isolate retail attention, since bookbuilding officially occurs later.

Da et al. (2011) use a continuous variable to capture retail attention, which comes at the cost of a smaller and less representative sample. By incorporating a dummy variable, our sample size is three times as large (although we also use the continuous attention variable as a robustness check). Our sample period is also longer. In their measurement of the change in retail attention (which is the key variable of interest in their paper and in ours), Da et al. (2011) ignore the fact that IPO registration periods differ in length and that critical information about a firm is revealed in filings prior to the offer date (most importantly, the initial filing, as discussed earlier), which could significantly distort retail attention around these events, thus making their benchmark SVI unstable and the change in SVI questionable. ${ }^{7}$ On the other hand, by clearly identifying the filing date and capturing the change in attention relative to this date, our benchmark SVI (captured prior to this date) is likely to be more stable, thus making the change in retail attention more reliable.

\footnotetext{
${ }^{7}$ For example, examining US firms over the 1986-2007 period, Bouis (2009) finds that only 0.5\% of firms go public within 30 calendar days (i.e., 4 weeks) from the initial filing. By contrast, $41 \%$ of firms take $31-$ 60 days (i.e., 5-8 weeks) while 33\% take 61-90 days (i.e., 9-12 weeks).
} 
In Section 2, we discuss the restrictions on communication between issuers/underwriters and prospective investors (mainly institutional) prior to initial valuation and how observing retail attention can help fill this void. We then present the data and retail attention measures (Section 3) and our initial valuation measures (Section 4). Descriptive statistics and univariate tests are analyzed in Sections 5 and 6, respectively. Our base regressions are presented in Section 7, while our more comprehensive regressions that include additional controls for institutional demand are captured in Section 8. Several robustness checks are performed in Section 9, and Section 10 discusses our conclusions.

\section{Communication restrictions and the importance of retail investor attention in valuation}

\subsection{Restrictions in communication between issuers/underwriters and prospective investors}

In the US, underwriters have traditionally been unable to engage in oral and written communication to a significant extent with prospective investors before the filing of a preliminary registration statement containing an initial price range (Latham and Watkins, 2014). By contrast, Jenkinson et al. (2006) highlight that, in Europe, issuers and underwriters have generally tended to obtain information from investors before setting an initial price range. In the US, a significant amount of information has usually been elicited by underwriters from institutional investors with the purpose of gauging interest in the IPO only after establishing the initial price range and during bookbuilding. The constraints that US underwriters have traditionally faced in gathering useful information from investors before filing a prospectus have their origins in regulations governing IPOs, their interpretation by lawyers, and their practical application.

During our sample period of 2004-2011 (i.e., before enactment of the JOBS Act in 2012), Section 5 of the Securities Act of 1933 did not allow issuers and underwriters to communicate with investors before the filing of a preliminary registration statement. Additionally, it was widely believed that Rule 15c2-8 of the Securities Exchange Act of 1934 imposed restrictions on issuers and underwriters that prevented them from soliciting offers and indications of interest from investors before filing of the prospectus (Practical Law, 2014). Some managers considered these rules and their implementation by practitioners much too 
restrictive, particularly for small, hard-to-value companies that would find it beneficial to obtain information on investor demand at a very early stage in the IPO process (Herper, 2013).

With the JOBS Act, some of the rules have been relaxed, at least for Emerging Growth Companies (EGCs). Issuers and underwriters of EGCs can now engage in "testing-the-waters" activities, even before filing a preliminary prospectus, to gauge investor interest in the offer (Dambra et al., 2015). The SEC also clarified in 2012 that the previous interpretation of Rule 15c2-8 was too conservative and that issuers and underwriters could actually seek indications of interest even before publishing a prospectus (Securities and Exchange Commission, 2012; Latham and Watkins, 2013; Practical Law, 2014). This clarification by the SEC may have affected the pricing of IPOs in the latter part of 2012 and later, a period not covered by our study. Overall, during our sample period, owing to existing laws and their interpretation by practitioners, issuers and underwriters probably had very few opportunities to directly communicate with potential investors to gauge their interest in an IPO before filing a prospectus containing an initial price range.

Further, the academic literature documents that institutional investor demand is not officially available when the initial price range is set (Hanley, 1993, pp. 231-32; Ljungqvist and Wilhelm, 2002, p. 178; Wang and Yung, 2011, p. 302; Chuluun, 2015, footnote 7). As mentioned by Wang and Yung (2011, p. 302) and Chuluun (2015, footnote 7), the SEC prohibits soliciting investor opinion before the initial price range is set. Chuluun (2015) further points out anecdotal evidence suggesting that reliable information about potential demand for the IPO is very scarce before filing the initial price range. Finally, Colaco et al. (2009) document that direct learning (from a firm's own bookbuilding efforts) and indirect learning (from contemporaneous offerings) may not be available at the initial filing.

\subsection{Initial valuation and the role of retail investor attention}

The importance of initial valuation to firms and underwriters is highlighted by Hanley and Hoberg (2010, p. 2826), who argue that significant resources are expended by a firm and its underwriters to acquire information that results in more precise initial valuation. Using textual analysis to distinguish the contents of the initial prospectus into "standard" and "informative" components, the authors argue that more informative content from the pre-market would result in more accurate initial valuation and reduce the need 
for information production during bookbuilding. Hanley and Hoberg (2010) imply that institutional interest is not available before filing of the initial price range. If it were, then it would not be necessary for firms and underwriters to engage in costly pre-market research activity, since the information could be readily obtained from institutional investors. Similarly, Kim and Ritter (1999, p. 411) posit that comparable firm multiples alone are not sufficient to ensure accurate pricing when determining the initial price range and that the market's demand for an IPO helps improve pricing accuracy. Furthermore, the IPO literature is replete with studies that directly or indirectly examine the price update between the initial and final valuations. For instance, examining the efficiency of the IPO pricing process, Lowry and Schwert (2004) find that the price update is $-1.4 \%$, on average.

The IPO academic literature with respect to retail investors is not as extensive as that for institutional investors. As pointed out by Barber and Odean (2008), retail attention may be a precursor of retail demand for shares in the aftermarket. On similar lines, Derrien (2005) and Ljungqvist et al. (2006) suggest that sentiment investors influence initial stock trading, and Dorn (2009) finds that IPOs that are aggressively bought by retail investors in the when-issued market are actively pursued by retail investors in the aftermarket. Derrien (2005) finds that, in France, the IPO price chosen is positively associated with the intrinsic value of the company (revealed by institutional investors) and noise trader sentiment. In a theoretical paper, Ljungqvist et al. (2006) find that the value to an issuer is maximized if issuers allocate shares to institutional investors, which are then sold over time to sentiment investors as they arrive. The authors conjecture that the excessive enthusiasm of retail investors results in greater underpricing in the short-term and underperformance in the long-term. Dorn (2009) studies German IPOs and finds that retail demand is associated with high underpricing and poor long-term performance.

Using a data set of 486 IPOs from 12 European countries between 1995 and 2002, Cornelli et al. (2006) find that high grey market prices, a measure of over-optimism, are positively correlated with firstday IPO returns and negatively correlated with IPO performance up to one year after going public. These authors provide evidence that grey market traders (typically retail investors and small institutions) generate valuable information despite their irrationality and argue that their results hold even for countries, like the 
US, that do not have grey markets. Cook et al. (2006) examine the benefits of the marketing of US IPOs by underwriters and find that marketing is beneficial because it boosts retail investor sentiment. Furthermore, examining a sample of firms from Taiwan that went public using the auction method, Chiang et al. (2010) find that the number of individual bidders is positively correlated with firm size, the technology industry, and the underpricing of recent auction IPOs, and negatively correlated with market volatility during the three months prior to the auction day.

Given the limited information environment resulting from communication restrictions and the influence that retail investors have over valuation, we expect firms and underwriters to incorporate retail investor attention into the initial valuation of an IPO firm. Specifically, the presence of retail attention prior to the initial pricing should be associated with higher initial valuations. The increase in retail attention following the initial filing (but prior to initial pricing) should also be related to a higher initial price.

\section{Data and attention measures}

Our initial sample consists of 1541 US IPOs from the Securities Data Corporation (SDC) New Issues database that went public from 2004 to 2011 . The sample period begins in 2004 because Google's SVI, our proxy for retail investor attention, is available only from this year onwards. All SVI data were obtained from Google Trends in November 2012. As in Da et al. (2011), we include only regular and common stock IPOs (CRSP share codes 10 and 11) that initially list on NYSE, AMEX, and NASDAQ if the first available CRSP closing price is available within five trading days of the IPO date. We also drop financial firms (SIC code 6xxx). Our sample reduces to 672 firms as a result. Da et al. (2011) report that valid SVI values are not available for some stocks because individuals may not use the SDC company name to search for the stock in Google. Further, Google Trends truncates the output and returns missing values for SVIs with insufficient searches. We use the company's name as our search term in Google Trends rather than the 
ticker symbol, since it is very likely that the latter is unknown to prospective investors, especially before the initial filing. ${ }^{8}$ We obtain weekly SVI data. ${ }^{9}$

We also require valid sales, earnings before interest, taxes, depreciation, and amortization (EBITDA), and total assets. We begin with the basic requirement that data on sales and total assets must be available on Compustat. An additional requirement is that the IPO firm must have shares outstanding before the IPO to obtain a meaningful pre-IPO valuation. Finally, we require that there be no missing data for our base regression model. As a result of the above restrictions, our base sample consists of 546 IPO firms. We hand-collect the filing and pricing dates, and the initial price range from the Electronic Data Gathering, Analysis, and Retrieval (EDGAR) system.

There are two key dates for our approach — filing date and pricing date-and our focus is on examining the impact of retail investor attention on initial valuation. We use raw SVI following the filing date (but prior to the pricing date) to capture the presence of attention, and the change in SVI around the filing date (but prior to the pricing date) to capture the change in attention. Raw SVI is computed by Google relative to other searches for the same term over the chosen period and is based on a benchmark of 100 for the maximum volume of searches. While these raw values can be compared across time for a given firm (e.g., an SVI of 100 implies four times as much search activity as an SVI of 25 for the same firm), they have limited meaning when compared across firms (e.g., an SVI of 100 for Firm A is not the same as an

\footnotetext{
${ }^{8}$ We include firms whose names have multiple meanings and exclude legal terminology (e.g., Inc, Corp, Co, Co Inc). For example, for "Blackboard Inc" we enter "Blackboard" in Google Trends. Since "blackboard" has an alternate meaning, including it in our sample should bias against our results.

${ }^{9}$ We run searches on Google Trends for the whole period January 2004 to November 2012. For some firms in our sample, our searches generate no output. For the remaining firms, Google Trends provides either weekly or monthly SVI data. We use only weekly data since it allows us to capture changes in attention more precisely.
} 
SVI of 100 for Firm B, since absolute levels of interest could differ significantly). We create dummy variables (discussed later) to counter some of the deficiencies associated with using SVI data.

Appendix A shows the timeline of events along with the retail investor attention measures that we use. Given our focus on initial valuation, we are interested in examining SVI around the filing date but prior to the pricing date. Filing $(0)$ indicates the week containing the filing date, while Filing $(+1)$ identifies the week following Filing $(0)$. Filing(-4) refers to the four weeks preceding Filing $(0)$. In addition, we track the change in SVI. Filing $(-4,+1)$ involves an SVI comparison between Filing(+1) and Filing(-4). Finally, Filing (-4,0) involves an SVI comparison between Filing(0) and Filing(-4).

In Table 1 Panel A, we show the summary statistics of the percentage change in retail investor attention around the filing date. Appendix A includes the definitions of variables specific to Table 1. $\%$ Attention change: Filing $(-1,+1)$ is $28 \%$, on average, indicating that SVI increases by that margin from Filing $(-1)$ to Filing $(+1)$. The median increase is $16 \%$. Note that we are able to compute this measure for only 186 out of our overall sample size of 546 firms. As another example, \% Attention change: Filing $(-4,+1)$ is $27 \%$, on average, indicating that SVI increases by that margin from Filing(-4) to Filing $(+1)$. These changes following the filing event are fairly large and raise questions about the stability of the benchmark SVI in Da et al. (2011), who ignore events prior to the offering. For example, the benchmark SVI of a firm computed during a period with no key events is likely to be more stable than that of another firm from Filing(-4) to Filing $(+1)$ given that the filing event occurs within this time window for the latter firm.

Focusing on the week containing the filing date, $\%$ Attention change: Filing $(-1,0)$ is $30 \%$, on average, indicating that SVI increases by that margin from Filing(-1) to Filing $(0)$. \% Attention change: Filing $(-4,0)$ is also $30 \%$, on average, indicating that SVI increases by that margin from Filing(-4) to Filing $(0)$. Once again, we observe that the percentage changes in attention are fairly large. From Panel A, note that both the mean and median values of all measures are positive, indicating that firm name search volume has increased. Panel B shows that, based on a paired t-test of difference in means, the percentage changes in SVI captured at Filing $(0)$ and Filing $(+1)$ are statistically similar. 


\section{Construction of initial valuation measures}

We use Purnanandam and Swaminathan (2004) as a guide to create our valuation measures. For our IPO sample firms, sales, EBITDA, and total assets are obtained from Compustat for the fiscal year ending just prior to the pricing date. ${ }^{10}$ For each IPO in our sample, we identify a firm from the same Fama and French (1997) industry with comparable sales and EBITDA profit margin (i.e., EBITDA/sales) that did not go public in the preceding three years. As Purnanandam and Swaminathan (2004) point out, this results in matching operating risks, profitability, and growth. Additionally, sales is a proxy for size (Cook et al., 2006). Further, EBITDA profit margin is used to capture firms with similar profitability. Bhojraj and Lee (2002) find that adjusting industry median multiples based on operating performance improves valuation accuracy. Further, Purnanandam and Swaminathan (2004) argue that using either a small or large list of characteristics to match firms is not ideal. Like these authors, we settle on industry, sales, and EBITDA profit margin as matching criteria to find matching firms.

To find a suitable match for each IPO in our sample, we perform the following steps. First, only matching firms that satisfy the following four criteria are kept: the matching firm must be from the same Fama and French (1997) industry; the fiscal year end date of the matching firm must precede the IPO pricing date; the difference between the pricing date and the fiscal year end date of the matching firm should not exceed one year; the difference between the pricing date of the IPO firm and the IPO offer date for the matching firm should be larger than three years. Second, the tercile of the remaining matching firms with sales data that is most similar to the sales of the IPO firm is retained. Third, based on the profit margin of the IPO firm, the most relevant tercile of the remaining matching firms is retained. Finally, within the remaining profit margin tercile, the matching observation with sales that are most similar to the sales of the IPO firm is identified.

\footnotetext{
${ }^{10}$ Due to the large number of negative and missing values, we do not consider earnings per share.
} 
As a robustness check, we rely on the propensity score matching procedure used in Chemmanur and Krishnan (2012). For each year, a probit model is run using a sample that includes the IPO firms and matching firms. In one specification, the independent variables are sales and profit margin. In another, we also include assets, net income divided by assets, and the present value of growth opportunities ( $P V G O$ index — defined in Appendix B). For each IPO firm, we identify the matching firm from the same Fama and French (1997) industry with the most similar probit predicted probability. The empirical findings are qualitatively similar when using the propensity score matching methods rather than the basic matching method, and are available on request.

For each firm in our IPO sample, we create three valuation measures: Price-to-Sales (IPO), Price-toEBITDA $_{(I P O)}$, and Price-to-Assets $(I P O)$. Sales and EBITDA are captured for the fiscal year ending prior to the pricing date, each in millions of dollars. Only observations with positive values of EBITDA are used, since negative values are not meaningful for valuation purposes. Assets is the book value of assets at the fiscal year ending prior to the pricing date, in millions of dollars. Purnanandam and Swaminathan (2004) argue that book values tend to be low for IPO firms prior to going public, and Liu et al. (2002) state that book values are poor measures of valuation. Nevertheless, we use Assets to complement our Sales valuation measure. The price multiples of our IPO firms are computed as follows:

$$
\begin{gathered}
\text { Price-to-Sales }{ }_{(I P O)}=\frac{\text { Midpoint of initial price range } \times \text { Shares outstanding before } I P O}{\text { Prior fiscal year Sales }} \\
\text { Price-to-Assets }{ }_{(I P O)}=\frac{\text { Midpoint of initial price range } \times \text { Shares outstanding before IPO }}{\text { Prior fiscal year Assets }} \\
\text { Price-to-EBITDA }_{(I P O)}=\frac{\text { Midpoint of initial price range } \times \text { Shares outstanding before IPO }}{\text { Prior fiscal year EBITDA }}
\end{gathered}
$$

Consistent with Hanley (1993), Bradley and Jordan (2002), Loughran and Ritter (2002), Lowry and Schwert (2004), and many other IPO studies that examine the price update, we use the midpoint of the initial price range as a point estimate of initial valuation. Unlike Purnanandam and Swaminathan (2004) who use shares outstanding at the close on the offer date. We use the number of shares outstanding before the IPO (i.e., number of shares outstanding at the close on the offer date minus number of primary shares offered in the IPO) in millions because our accounting variables are captured before the IPO. 
Similarly, for each matching firm, we create three valuation measures: Price-to-Sales (Match), Price-

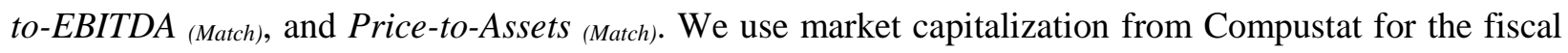
year ending prior to the pricing date of the IPO firm as the numerator for our valuation measures, while the three denominators are captured for the fiscal year ending prior to the pricing date of the IPO.${ }^{11}$ The ratios that we are interested in are those of the IPO firm to the matched firm, as shown below.

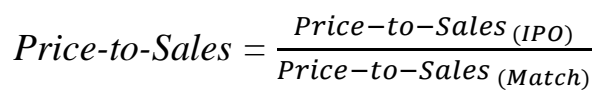

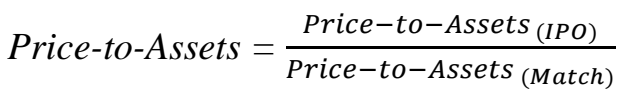

$$
\begin{aligned}
& \text { Price-to-EBITDA }=\frac{\text { Price-to-EBITDA }{ }_{(I P O)}}{\text { Price-to-EBITDA }(\text { Match })}
\end{aligned}
$$

Median Price-to-Sales is 1.85, median Price-to-Assets is 2.21, and median Price-to-EBITDA is 1.18 (see Table 2 Panel A). Comparing our Price-to-Sales and Price-to-EBITDA with those in the much larger sample in Purnanandam and Swaminathan (2004), our values are slightly higher and lower, respectively.

\section{Descriptive statistics of other variables}

In Table 2 Panel B, we provide descriptive statistics for the control and other meaningful variables, whose definitions can be found in Appendix B. Liu et al. (2014) find that pre-IPO media coverage is positively related to the firm's long-term value, liquidity, analyst coverage, and institutional investor ownership. Cook et al. (2006) refer to the same as "pre-offer publicity" and posit that effective promotional efforts about the firm in the media during the six months prior to going public result in greater publicity for the IPO. These authors find that more than $93 \%$ of articles appear between the filing and offering dates.

For our purposes, we need to control for institutional attention to obtain unbiased results for retail attention. The strong positive association between media coverage during registration and institutional

\footnotetext{
${ }^{11}$ Unlike Purnanandam and Swaminathan (2004), we use capitalization from Compustat, because CRSP captures only one class of outstanding shares.
} 
interest, as found in Liu et al. (2014), gives us confidence that media coverage is a good proxy for institutional investor attention. Media coverage between the filing and pricing dates is 0.31 (median). Since the period between filing and pricing differs for each firm, this media variable is scaled by the number of days during the period, Days, which itself has a median value of almost three months (12 SVI weeks, approximately).

The University of Michigan Consumer Sentiment Index (UMCS) is a monthly survey of US consumer confidence that basically asks households about their economic outlook (Ludvigson, 2004; Da et al., 2015). Da et al. (2015) find a high correlation between the SVI for the term "recession" and UMCS. Thus, UMCS reflects broad consumer sentiment, which could impact firm valuation. We examine the change in UMCS by comparing UMCS for the month containing the pricing date with that for the prior month. The average value is zero, indicating no change in consumer sentiment.

The median underwriter rank (proxy for reputation) is 8.5. Given that it is quite close to its maximum value of 9 , one can conclude that firms prefer to choose high-reputation underwriters to take them public. Some $47 \%$ of our sample firms are backed by venture capitalists. Overhang reflects the ratio of retained shares to shares filed and has a median value of 2.67. We control for firm size and age, since these factors may affect valuation. Examining publicly traded companies, Frieder and Subrahmanyam (2005) find strong evidence that institutional holdings are related to firm size and argue that this occurs to avoid perceptions of excessive speculation in small firms and that investing in large firms reduces liquidity concerns if unexpected trading is necessary. Thus, firm size is also a proxy for institutional interest.

The median firm at the IPO is 11 years old and has 87 million dollars and 85 million dollars in assets and sales, respectively. Two-thirds of sample firms list on NASDAQ and, but for five firms that list on AMEX, the remaining firms list on NYSE. Following Benveniste et al. (2003), the extent to which the expected offer price reflects the present value of growth opportunities (PVGO) rather than the earnings from assets in place is measured using the $P V G O$ index. On average, $73 \%$ of the initial valuation incorporates future growth opportunities. This reflects the speculative nature of the typical offering. Finally, the average market return for the 90 trading days before the pricing date is $6 \%$. 


\section{Univariate tests}

To examine the presence of retail investor attention on IPO valuation, we first define the following dummy variables (see Appendix A). Attention dummy: Filing $(+1)$ equals one if the SVI for Filing $(+1)$ is greater than zero, and zero otherwise. Thus, firms that have SVI data for this week take a value of one while firms that don't have SVI data take a value of zero. This variable is designed to capture the presence or otherwise of retail investor attention following the filing date and to counter the deficiency associated with using raw SVI data discussed earlier. Similarly, Attention dummy: Filing(-4) equals one if the average weekly SVI for Filing(-4) is greater than zero, and zero otherwise. This variable reflects the presence or otherwise of retail attention prior to the filing date.

The following dummy variables are designed to capture the change in retail investor attention on IPO valuation (see Appendix A). Using dummy variables enables us to use our entire data set as opposed to being restricted to firms with only SVI data, as is evident from Table 1. Increased Attention dummy: Filing $(-4,+1)$ equals one if the SVI for Filing $(+1)$ is greater than that for Filing(-4), and zero otherwise. Similarly, No Increased Attention dummy: Filing $(-4,+1)$ equals one if the SVI for Filing $(+1)$ is less than or equal to that for Filing(-4), and zero otherwise. Both these variables are designed to capture the change in retail attention following the filing date.

Table 3 Panel A shows the Pearson correlations of our three initial valuation measures and retail investor attention variables. Attention dummy: Filing $(+1)$ is positively associated with Price-to-Sales, Price-to-Assets, and Price-to-EBITDA, each significant at the 5\% level. Note that the correlation between the valuation measures and Attention dummy: Filing (-4) is lower, indicating that the association between retail attention and valuation is stronger after rather than before the initial filing. Increased Attention dummy: Filing $(-4,+1)$ is positively associated with Price-to-Sales, Price-to-Assets, and Price-to-EBITDA, indicating a statistically significant positive association between the increase in retail investor attention and initial valuation. No Increased Attention dummy: Filing $(-4,+1)$ is negatively associated with each valuation 
measure, although none of the correlations are significant. We conclude that there is evidence of an association between both the presence of and an increase in retail investor attention and initial valuation.

We next examine more directly whether our valuation measures are significantly different for firms with and without retail investor attention. In Panel B, average Price-to-Sales for firms with retail investor attention for Filing $(+1)$ is 5.14 (median 2.61), while the corresponding value for firms without the same is 3.17 (median 1.63). A t-test of difference in means is highly significant, as is the Wilcoxon rank sum test of difference in distributions. Thus, initial valuation is higher for firms with SVI for Filing $(+1)$. Note that $36 \%$ of our sample firms have SVI data available for this measure. For Filing(-4), mean Price-to-Sales is 4.93 (median 2.46) for firms with attention and 3.34 (median 1.69) for firms without attention. The difference in means (and distributions) is once again highly significant. Proceeding to the next valuation measure, average Price-to-Assets for firms with SVI data for Filing $(+1)$ is 6.32 (median 3.24), and the corresponding value for firms with no SVI data is 4.03 (median 1.67); the difference is highly significant. Results are very similar for Filing(-4). Finally, average Price-to-EBITDA for firms with attention for Filing $(+1)$ is 3.67 (median 1.70) and the corresponding value for firms without attention is 2.39 (median 0.99). Once more, the t-test and Wilcoxon rank sum test show significant differences in the two groups. Results are somewhat similar for Filing(-4).

The results in Panel C show that both mean and median Price-to-Sales are higher when there is an increase in attention (Increased Attention dummy: Filing $(-4,+1)=1$ ) as compared to when there is a decrease or no change (No Increased Attention dummy: Filing $(-4,+1)=1$ ). The t-test and rank sum test are both highly significant. Note that $74 \%$ of firms experience an increase in attention following the filing date. Focusing on Price-to-Assets and Price-to-EBITDA, we find that the magnitude of valuations is significantly higher for firms with an increase in attention as compared to when there is a decrease or no change. We conclude that retail investor attention is associated with higher initial valuations.

We next examine whether some of our control variables are associated with the presence of and an increase in retail investor attention (Table 4). These variables are included in our base regressions. Media coverage between filing and pricing, underwriter reputation, and overhang are significantly higher for firms 
with retail attention (Panel A). Interestingly, growth opportunities are likely to be lower for these firms. There is also evidence that these firms are larger based on assets and sales. However, there appears to be no significant difference between the two groups with respect to consumer sentiment, venture capital (VC)backing, firm age, stock exchange listing, and market performance. Smaller (based on sales) and younger firms appear to experience a significant increase in retail attention following a filing (Panel B). Increased attention firms also have greater overhang and are more likely to be listed on NASDAQ. Note that there are only NYSE and NASDAQ firms in this subsample. The remaining variables are not significantly different between the two groups. One observation from Table 4 is that media coverage is associated only with the presence of, and not the increase in, retail investor attention. If institutional demand is linked to media coverage, then we can conclude that institutional interest does not influence the increase in attention after filing. Furthermore, the change in broad consumer sentiment appears to have no influence on attention. Thus, in a univariate setting at least, the influence of institutional interest and market sentiment over retail attention appears to be quite limited.

\section{Base regressions}

Our multivariate tests examine the relationship between the presence of and change in retail attention and our three valuation measures. Changes in consumer sentiment and media coverage between filing and pricing are included as control variables, as they may impact valuation. We include underwriter rank, venture capital, PVGO index, overhang, NYSE, NASDAQ, market return, and the natural logarithm of assets, sales, one plus age, and year and Fama and French (1997) 48 industry dummies as additional control variables. ${ }^{12}$ Standard errors are adjusted for clustering within the same year based on the pricing date. Clustered standard errors are considered to be more conservative than White (1980) errors.

\footnotetext{
${ }^{12}$ We generally use Ln(Assets) as firm size control, but we instead consider $\operatorname{Ln}($ Sales $)$ in the Price-to-Assets regressions since assets is used to create the valuation measure.
} 
In Table 5 Panel A, the dependent variables are Price-to-Sales (Columns 1, 2), Price-to-Assets (Columns 3, 4), and Price-to-EBITDA (Columns 5, 6). Our variables of interest are Attention dummy: Filing (+1) and Attention dummy: Filing(-4), which reflect the presence of attention on either side of the filing date. Attention dummy: Filing $(+1)$ is positively correlated with Price-to-Sales (Column 1), Price-toAssets (Column 3), and Price-to-EBITDA (Column 5) at least at the 5\% level of significance. Attention dummy: Filing(-4) is positively correlated with Price-to-Assets (Column 4) only at the 5\% level. For each valuation measure, the coefficient of Attention dummy: Filing $(+1)$ is higher than that for Attention dummy: Filing(-4), indicating that the presence of retail investor attention following the filing has a greater association with valuation.

With respect to economic significance, the presence of retail attention (based on Column 1) is related to an increase in Price-to-Sales of 1.499 (i.e., around one-third of the standard deviation of Price-to-Sales of 4.69). Thus, the economic significance of the relationship between the presence of retail attention and initial IPO valuation is quite large. In terms of the control variables, larger firms have lower valuations, as found in Chemmanur and Krishnan (2012). To put it differently, IPO valuation is largely based on future growth opportunities as opposed to earnings from assets in place, as stated earlier. This is confirmed by the positive sign on $P V G O$ index. Valuation is also positively correlated with the level of overhang. Older firms have lower valuations. There is some evidence that valuation is higher for firms that hire high-reputation underwriters and are backed by VCs. Consumer sentiment, media coverage between filing and pricing dates, and recent market performance have no impact on valuation. ${ }^{13}$

${ }^{13}$ Our results are qualitatively similar if we, instead, use as our market proxy the value weighted index returns for 30 or 90 trading days prior to the pricing date or equal weighted index returns for 30 trading days prior to the same date. Note that Columns 5 and 6 report no values for $N A S D A Q$ because this reduced sample has no firms that list on AMEX (the same occurs in Panel B). As a result, there are only NYSE and NASDAQ firms in these regressions. 
In Table 5 Panel B, we find that Increased Attention dummy: Filing $(-4,+1)$ is positively significant, indicating that positive changes in retail attention following the filing event are related to higher valuations. This variable remains significant even after controlling for the subgroup of firms with decreased or no change in retail attention (No Increased Attention dummy: Filing $(-4,+1))($ Columns 2, 4, 6), which itself is not significant. An increase in retail attention (based on Column 1) is associated with an increase in Priceto-Sales of 1.548 (i.e., around one-third of the standard deviation of Price-to-Sales). Thus, the economic significance of the relationship between the increase in retail attention and the initial IPO valuation is also quite large. In terms of the control variables, the results are qualitatively similar to those in Panel A.

\section{Institutional demand and promotional efforts of underwriters}

In Section 2, we discussed the communication embargo between issuers/underwriters and prospective investors prior to the filing of the initial price range. Nevertheless, informal (albeit illegal) communication between parties could exist, which we are obviously unable to capture. Our focus on initial valuation assumes that we can isolate retail attention from institutional demand given that communication is only officially permitted after the initial price range is revealed. In our base regressions (Table 5) discussed in the previous section, we include variables that directly or indirectly reflect the level of institutional interest in the IPO: media coverage between filing and pricing, and firm size. Our regression results show that retail attention is associated with IPO valuation after including these control variables. In this section, we include more controls, which we classify under two headings: institutional demand and promotional efforts.

\subsection{Institutional demand}

The percentage change from the midpoint of the initial price range to the offer price, commonly referred to as the price update, is used by numerous IPO studies to reflect institutional interest (e.g., Lowry and Schwert, 2004; Cook et al., 2006; Jeon et al., 2015). Furthermore, institutional ownership percentage and number of institutional owners after the IPO more directly capture institutional demand. These three variables are captured subsequent to initial valuation. We also include media coverage for the month prior 
to filing as an additional control variable. ${ }^{14}$ The new regressions are reported in Table 6 Panels A and B. In line with the results from Panel A of Table 5, Attention dummy: Filing $(+1)$ remains positively significant after including the above controls, while Attention dummy: Filing(-4) is positive and significant only in the Price-to-Assets model. In economic terms, the presence of retail attention (based on Column 5 of Panel A) is related to an increase in Price-to-EBITDA of 1.242 (i.e., almost one-third of the standard deviation of Price-to-EBITDA of 4.14).

In Panel B we find that our variable of interest, Increased Attention dummy: Filing $(-4,+1)$, remains positively significant in all our regression models after inclusion of the institutional demand controls. An increase in retail attention (based on Column 5 of Panel B) is associated with an increase in Price-toEBITDA of 1.335 (i.e., more than one-third of the standard deviation of Price-to-EBITDA of 3.61). Turning to the institutional demand controls, there is some evidence that valuations are higher when more institutional investors own shares in the firm. In conclusion, including the institutional demand proxies does not affect our core results. Recall that our base regressions already include variables that reflect institutional interest (i.e., media coverage between filing and pricing, firm size), which is probably why these additional controls have limited ability to explain valuation.

\subsection{Promotional efforts}

Investor interest could drive IPO valuations up, but demand by investors can be stimulated. Investor interest may stem from the promotional efforts of underwriters to sell shares in the IPO. This may be particularly true for retail investor interest and attention. For example, Cook et al. (2006) employ measures of media coverage and examine the impact of firm publicity about the upcoming IPO on retail demand after the IPO, the implication being that the publicity leads to greater retail demand for the shares, which benefits

${ }^{14}$ In unreported results, as in Cook et al. (2006) and Jeon et al. (2015), the median price update is zero, indicating that the midpoints of the initial price range and offer price are the same. This reflects the importance of the initial valuation and the role of retail attention since, for the median firm, the final valuation is merely a confirmation of the initial valuation (ignoring other factors that influence valuation). 
issuers, underwriters, and institutional investors. These authors also report a positive relationship between pre-offer publicity and IPO offer prices, an indication that underwriters can rely on promotional efforts to boost IPO valuations. Further, Jeon et al. (2015) find that post-IPO institutional holdings are approximately 4.4\% higher when multiple lead underwriters (MLUs) are involved with the IPO, as opposed to hiring a single lead underwriter. Moreover, if more co-managers are associated with an IPO, this could lead to more institutional interest, since each co-manager would have its own clientele. Finally, greater underwriter compensation via the gross spread could increase the level of effort to promote an IPO and generate investor interest. We include these variables as additional controls to those in our base regressions, since they may cause an increase in retail investor attention that could simply be a by-product of promotional efforts by underwriters, which may have a direct effect on IPO valuations. As in the previous subsection, we also include media coverage for the month prior to filing as an additional control variable.

Table 7 Panel A shows that the presence of retail attention continues to be positively associated with valuation after including the above controls. The presence of retail attention (based on Column 1 of Panel A) is related to an increase in Price-to-Sales of 1.375 (i.e., almost 30\% of the standard deviation of Priceto-Sales of 4.69). Panel B shows that Increased Attention dummy: Filing $(-4,+1)$ is positively significant in all regression models. An increase in retail attention (based on Column 1 of Panel B) is associated with an increase in Price-to-Sales of 1.479 (i.e., around one-third of the standard deviation of Price-to-Sales). All control variables in Panels A and B are statistically insignificant.

In conclusion, we generate notable evidence of a positive correlation between the presence of and an increase in retail investor attention and IPO valuation after controlling for direct and indirect proxies for institutional demand. While we cannot entirely rule out the possibility of omitted variables (e.g., informal private conversations between institutional investors and underwriters/issuers about firm valuation before the initial valuation is announced) and reverse causality biases (e.g., underwriters and issuers deciding the level of their promotional efforts depending on expected IPO valuations), our empirical study provides strong and convincing evidence that retail investor attention matters and that underwriters do incorporate it into firm valuation. 


\section{Robustness checks}

\subsection{Continuous attention variable}

Until now, we have a used a dummy variable to capture the change in attention following the filing of the S-1. To measure retail attention, Da et al. (2011) compare SVI during the week prior to the week containing the offer with the median SVI during the prior 4-, 6-, 8-, and 10-weeks. By contrast, we compute the change in attention relative to the filing date and, as Table 1 Panel A clearly shows, on average (and based on the median), there is an increase in retail attention after filing. We rerun our base regressions after replacing the dummy attention variables with $\%$ Attention change: Filing $(-4,+1)$ as our continuous attention variable. Since we can include firms only where we can compute a percentage change in attention, our sample size drops significantly. For example, comparing Table 5 Panel B with Table 8, the number of observations in our Price-to-Sales and Price-to-Assets regressions drastically declines from 546 to 188 and that in our Price-to-EBITDA regressions from 359 to 137. In addition, the reduced sample likely reflects firms that are similar to one another, thus significantly reducing cross-sectional variation and further decreasing the statistical significance of our findings. Examining the results from Table 8, we find that when retail attention increases, Price-to-EBITDA also increases. Thus, even after capturing the change in attention as a continuous variable instead of as a dummy, we report a positive correlation between change in attention and IPO valuation, at least for one of our valuation measures.

\subsection{Retail attention during filing week}

We have used the week following the filing date (i.e., week +1$)$ rather than the week containing the filing date (i.e., week 0) in our tests. As per Da et al. (2011, Figure 2), SVI peaks during the week containing the offer date. Similarly, it would not be unreasonable to expect SVI to be higher during the filing week than a week later (in fact, Table 1 shows evidence that this is, indeed, the case). The problem with using week 0 as opposed to week +1 is that we are not certain if we are capturing retail investor attention after the filing, since the filing could occur on any day of the week. Hence, using week +1 is a safer option. Nevertheless, we rerun our base regressions (Table 5) after recreating our attention variables as of week 0 
instead of week +1 . Attention dummy: Filing $(0)$ and Increased Attention dummy: Filing $(-4,0)$ remain highly positively significant in most regressions (unreported), thus consistent overall with our earlier findings.

\subsection{Initial valuation based on low and high of initial price range}

In examining the relationship between retail attention and initial valuation, we have used the midpoint of the initial price range as the point estimate of initial firm value for the IPO firm. While this measure is taken as a proxy for initial IPO valuation by many studies (Hanley, 1993; Lowry and Schwert, 2004), the possibility remains that any price within the range could be justified as the firm's initial value point estimate, and the relationship with attention may differ based on the point estimate used. So, to examine whether our results are robust to other prices in the range, we replace the midpoint of the initial price range with, first, the low of the range and, next, the high of the range. We then rerun our base regressions (Table 5) based on the newly created valuation measures. Once again, our results (available on request) remain qualitatively similar to those in our base regressions.

\subsection{Seasonality}

Google searches are unlikely to be stable during the year and may increase or decrease significantly during certain periods. For example, during the holiday period in the US (i.e., Thanksgiving - Christmas New Year's Day) there may be an increase in online search for retailers. If anything, this should bias against us finding any results. Moreover, our key retail attention measure compares SVI one week after the event with the average SVI for the four weeks prior to the event, thus significantly reducing any seasonality issues.

\subsection{Textual analysis}

It is possible that the firm quality controls in our regressions are inadequate, with the result that our attention dummies proxy, in fact, for firm quality rather than attention. Textual analysis of SEC filings has helped researchers gain a deeper insight into firm quality by focusing on the tone of the filings. Hanley and Hoberg (2010) find that the tone of the prospectus is associated with IPO pricing accuracy. Specifically, greater informative content results in a lower absolute price update between initial valuation and offering. To capture a firm's business strategy and operations, they characterize words as uncertain, weak modal, 
negative, positive, legal, and strong modal; Loughran and McDonald (2013) examine the influence of the tone on IPO valuation. We obtain textual analysis data at the S-1 filing for 461 of our base sample of 546 firms. ${ }^{15}$ Simple correlations between our retail attention dummy variables and the word characterizations are less than $10 \%$ in absolute value. Our multivariate results that include the textual analysis variables one at a time (unreported) show that our key variables, Attention dummy: Filing $(+1)$ and Increased Attention dummy: Filing $(-4,+1)$, remain highly significant in most specifications, consistent with the findings in our base regressions. The textual variables themselves are mostly not significant. Overall, we conclude that our results remain robust to inclusion of these variables.

\section{Summary and conclusion}

We examine the relationship between retail investor attention based on SVI from Google Trends and initial IPO valuation for a sample of US IPOs for the period 2004-2011. By examining initial valuation, we focus on retail investor interest, since institutional investor demand as reflected in bookbuilding officially commences only after the initial pricing. We find that the presence of and an increase in retail attention following the initial filing but prior to initial pricing are associated with higher initial valuations as captured by Price-to-Sales, Price-to-Assets, and Price-to-EBITDA. Our results are robust to including basic and propensity score matching methods to identify our matched sample, the low, midpoint, or high of the initial price range as the point estimate for our valuation measures, a battery of direct and indirect controls reflecting institutional interest, and firm-specific controls including textual analysis. We conclude that, in the absence of institutional demand, retail investor attention plays an important role in initial IPO valuation despite the fact that retail investors are often considered irrational.

\footnotetext{
${ }^{15}$ We thank Professor Bill McDonald for making this data available on his website.
} 


\section{Appendix A}

\section{IPO retail investor attention measures}

IPO timeline: from filing of initial S-1 (or equivalent) to offer date

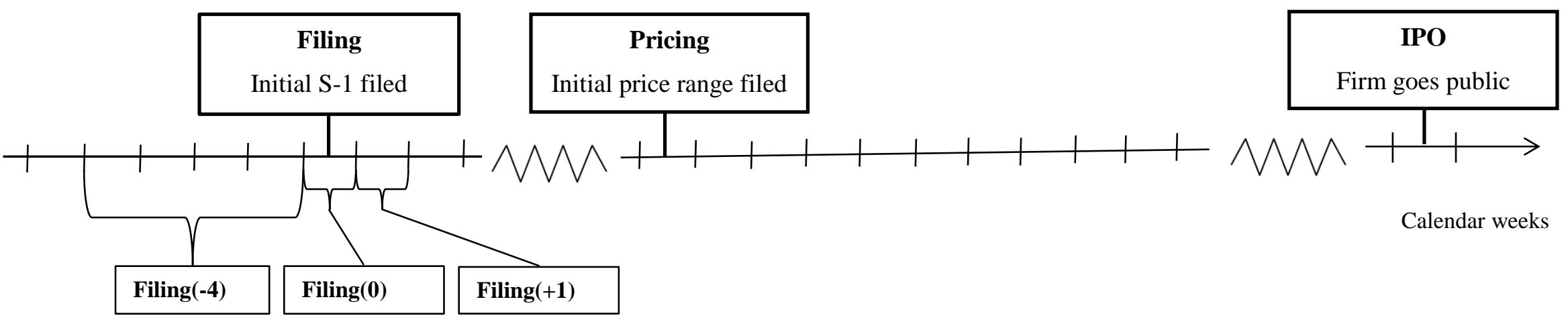

Notes:

1. Filing $(0)$ indicates the week containing the filing date (i.e., date of initial S-1 (or equivalent) filing).

2. Filing $(+1)$ identifies the week following Filing $(0)$.

3. Filing(-4) refers to the four weeks preceding Filing(0). 


\section{Definition of attention variables in Tables 1 and 8}

\% Attention change: Filing $(-1,+1)$ is the percentage change in Google Trends Search Volume Index (SVI) from Filing(-1) to Filing $(+1)$, where Filing(-1) is the week before Filing $(0)$.

$\%$ Attention change: Filing $(-2,+1)$ is the percentage change in SVI from Filing(-2) to Filing $(+1)$, where Filing(-2) refers to the two weeks preceding Filing (0). The average weekly SVI for Filing(-2) is used to compute the percentage change.

Similarly, \% Attention change: Filing $(-3,+1)$ and \% Attention change: Filing $(-4,+1)$ are percentage changes in SVI from, respectively, Filing(-3) and Filing(-4) to Filing(+1).

$\%$ Attention change: Filing $(-1,0)$ is the percentage change in SVI from Filing(-1) to Filing $(0)$.

\% Attention change: Filing (-2,0) is the percentage change in SVI from Filing(-2) to Filing(0), where Filing(-2) refers to the two weeks preceding Filing $(0)$. The average weekly SVI for Filing(-2) is used to compute the percentage change.

Similarly, \% Attention change: Filing(-3,0) and \% Attention change: Filing(-4,0) are percentage changes in SVI from, respectively, Filing(-3) and Filing(-4) to Filing(0).

Notes:

1. Each of the above variables is winsorized at its $5 \%$ and $95 \%$ values.

2. SVI weeks and periods are defined in the IPO timeline.

3. The percentage changes in attention can be computed only if SVI is available.

4. We do not include firms in our sample for which the filing and pricing events occur during the same SVI week or one SVI week apart, since we cannot compute the percentage changes in attention.

\section{Definition of attention variables in Tables 3-7}

Attention dummy: Filing $(0)$ equals one if Google Trends Search Volume Index (SVI) for week Filing $(0)$ is greater than zero, and zero otherwise.

Attention dummy: Filing (+1) equals one if SVI for Filing $(+1)$ is greater than zero, and zero otherwise. 
Attention dummy: Filing(-4) equals one if the average weekly SVI for Filing(-4) is greater than zero, and zero otherwise.

Increased Attention dummy: Filing $(-4,+1)$ equals one if SVI for Filing $(+1)$ is greater than the average weekly SVI for Filing(-4), and zero otherwise.

No Increased Attention dummy: Filing $(-4,+1)$ equals one if SVI for Filing $(+1)$ is less than or equal to the average weekly SVI for Filing(-4), and zero otherwise.

Increased Attention dummy: Filing $(-4,0)$ equals one if SVI for Filing $(0)$ is greater than the average weekly SVI for Filing(-4), and zero otherwise.

No Increased Attention dummy: Filing $(-4,0)$ equals one if SVI for Filing $(0)$ is less than or equal to the average weekly SVI for Filing(-4), and zero otherwise.

Notes:

1. SVI weeks and periods are defined in the IPO timeline.

2. If SVI is not available, it is assigned a value of zero and is thus treated the same as when SVI is actually zero.

3. We do not include firms in our sample for which the filing and pricing events occur during the same SVI week or one SVI week apart, since we cannot compute the attention variables.

4. SVI for both Filing(-4) and Filing (+1) could equal zero, indicating no change in SVI, which would suggest that the dummy variable No Increased Attention dummy: Filing $(-4,+1)$ should equal one. However, in such case, No Increased Attention dummy: Filing $(-4,+1)$ would not equal one and instead would take a value of zero, since it does not really indicate no change in SVI (since zero SVI indicates no or a very low number of searches). On the other hand, No Increased Attention dummy: Filing $(-4,+1)$ would equal one if the SVI for Filing $(-4)$ and that for Filing $(+1)$ were both equal to ten, for example, since it reflects a meaningful number of searches. If the SVI for Filing(-4) is zero and that for Filing $(+1)$ is ten, for example, Increased Attention dummy: Filing $(-4,+1)$ would equal one. If the reverse occurs, No Increased Attention dummy: Filing $(-4,+1)$ would equal one. 


\section{Appendix B}

\section{Definition of other variables}

All variables are obtained from Securities Data Corporation New Issue database (SDC) unless otherwise stated. All dollar values are adjusted for inflation using the GDP Implicit Price Deflator (2011 prices).

\section{Valuation measures}

Price-to-Assets is Price-to-Assets (IPO) divided by Price-to-Assets (Match). Price-to-Assets (IPO) is the midpoint of initial price range times shares outstanding before the IPO (from CRSP, Compustat, and filings) divided by prior fiscal year Compustat Assets of the IPO firm. Price-to-Assets (Match) is prior fiscal year Compustat Market capitalization divided by prior fiscal year Compustat Assets of the matching firm. Price-to-Assets is winsorized at its $5 \%$ and $95 \%$ values.

Price-to-EBITDA is Price-to-EBITDA (IPO) divided by Price-to-EBITDA (Match). Price-to-EBITDA $(I P O)$ is the midpoint of initial price range times shares outstanding before the IPO (from CRSP, Compustat, and filings) divided by prior fiscal year Compustat EBITDA of the IPO firm. Price-toEBITDA (Match) is prior fiscal year Compustat Market capitalization divided by prior fiscal year Compustat EBITDA of the matched firm. Price-to-EBITDA is winsorized at its $5 \%$ and $95 \%$ values.

Price-to-Sales is Price-to-Sales (IPO) divided by Price-to-Sales (Match). Price-to-Sales (IPO) is the midpoint of initial price range times shares outstanding before the IPO (from CRSP, Compustat, and filings) divided by prior fiscal year Compustat Sales of the IPO firm. Price-to-Sales (Match) is prior fiscal year Compustat Market capitalization divided by prior fiscal year Compustat Sales of the matched firm. Price-to-Sales is winsorized at its $5 \%$ and $95 \%$ values.

\section{Other variables}

Age is difference in years between the year of the offer and the founding year. We use the Field-Ritter data set of founding dates (Field and Karpoff, 2002; Loughran and Ritter, 2004), obtained from Professor Jay Ritter's website. The variable is winsorized at its $95 \%$ value.

Assets is Compustat total assets in millions of dollars for the fiscal year ending prior to the pricing date. The variable is winsorized at its $5 \%$ and $95 \%$ values. 
Change in UMCS is the difference between the value of the University of Michigan Consumer Sentiment Index for the month containing the pricing date and the value of the same index for the prior month.

Days is number of calendar days between filing and pricing dates, not including both dates.

Gross spread is percentage of IPO proceeds paid to underwriters.

Institutional ownership is percentage of share ownership in the IPO firm by institutions as of the first quarter after the IPO from the Thomson Reuters Institutional Holdings (13F) database. The variable is winsorized at its $95 \%$ value.

Market return: 90 days before pricing is the CRSP equal weighted index return for 90 trading days ending one day before the pricing date. The variable is winsorized at its $5 \%$ and $95 \%$ values.

Media: filing to pricing is one plus the total number of articles from LexisNexis that include the name of the company for the period between the initial filing date and the initial pricing date, all divided by Days. The variable is winsorized at its $95 \%$ value.

Media: month before filing is one plus the total number of articles from LexisNexis that include the name of the company for one month up to the initial filing date (including both dates), divided by the number of calendar days during the period. The variable is winsorized at its $95 \%$ value.

$M L U$ equals one if the IPO has more than one lead underwriter, and zero otherwise.

NASDAQ equals one if IPO is listed on NASDAQ, and zero otherwise.

Number of co-managers is the number of co-managers in the underwriting syndicate. The variable is winsorized at its $95 \%$ value.

Number of institutional investors is the number of institutional investors in the IPO firm as of the first quarter after the IPO from Thomson Reuters Institutional Holdings (13F) database. The variable is winsorized at its $95 \%$ value.

NYSE equals one if the IPO is listed on the New York Stock Exchange, and zero otherwise.

Overhang is number of shares outstanding after IPO minus shares offered in the IPO, all divided by the sum of primary and secondary shares initially filed. Overhang is winsorized at its $95 \%$ value. 
Price update is offer price minus midpoint of initial price range, all divided by midpoint of initial price range times 100 . The variable is winsorized at its $5 \%$ and $95 \%$ values.

PVGO index, measured as in Benveniste et al. (2003), is as follows:

$$
P V G O \text { index }=\frac{\text { Midpoint of initial price range }-\frac{E P S}{\text { Industry cost of capital }}}{\text { Midpoint of initial price range }}
$$

where:

Midpoint of initial price range is average of high and low prices of initial price range.

EPS is Compustat fully diluted earnings per share excluding extraordinary items for fiscal year ending prior to IPO.

Industry cost of capital is the sum of the monthly industry risk premium estimate and the monthly risk free rate (over the period 1970-2011), all times 12. For each Fama and French (1997) industry, the monthly risk premium is the sum of the products of estimated loadings for the three Fama-French factors and the momentum factor (estimated through a time-series OLS regression) and the average monthly values of their respective risk factors. All the monthly data required are obtained from Professor Ken French's website.

PVGO index equals one if EPS is negative. Also, if capitalized EPS exceeds the midpoint of initial price range (i.e., numerator is negative), $P V G O$ index is set to zero.

Sales is Compustat total sales in millions of dollars for the fiscal year ending prior to the pricing date. The variable is winsorized at its $5 \%$ and $95 \%$ values.

Underwriter rank is ranking of lead underwriter based on Carter and Manaster (1990) ranking and updated on Professor Jay Ritter's website. If there is more than one lead underwriter, the average rank is taken.

Venture capital equals one if the firm is backed by a venture capitalist, and zero otherwise. 


\section{References}

Aggarwal, R., Prabhala, N. R. and Puri, M., "Institutional Allocation in Initial Public Offerings: Empirical Evidence," Journal of Finance, Vol. 57(3), 2002, pp. 1421-42.

Bae, K.-H. and Wang, W., "What's in a "China" Name? A Test of Investor Attention Hypothesis," Financial Management, Vol. 41(2), 2012, pp. 429-55.

Barber, B. M. and Odean, T., "All That Glitters: The Effect of Attention and News on the Buying Behavior of Individual and Institutional Investors," Review of Financial Studies, Vol. 21(2), 2008, pp. 785-818.

Benveniste, L. M., Ljungqvist, A., Wilhelm, W. J. and Yu, X. Y., "Evidence of Information Spillovers in the Production of Investment Banking Services," Journal of Finance, Vol. 58(2), 2003, pp. 577608.

Bhojraj, S. and Lee, C., "Who Is My Peer? A Valuation-Based Approach to the Selection of Comparable Firms," Journal of Accounting Research, Vol. 40(2), 2002, pp. 407-39.

Bouis, R., "The Short-Term Timing of Initial Public Offerings," Journal of Corporate Finance, Vol. 15(5), 2009, pp. 587-601.

Bradley, D. J. and Jordan, B. D., "Partial Adjustment to Public Information and IPO Underpricing," Journal of Financial and Quantitative Analysis, Vol. 37(4), 2002, pp. 595-616.

Carter, R. B. and Manaster, S., "Initial Public Offerings and Underwriter Reputation,” Journal of Finance, Vol. 45(4), 1990, pp. 1045-67.

Chemmanur, T. J. and Krishnan, K., "Heterogeneous Beliefs, IPO Valuation, and the Economic Role of the Underwriter in IPOs," Financial Management, Vol. 41(4), 2012, pp. 769-811.

Chiang, Y.-M., Qian, Y. and Sherman, A. E., "Endogenous Entry and Partial Adjustment in IPO Auctions: Are Institutional Investors Better Informed?" Review of Financial Studies, Vol. 23(3), 2010, pp. 1200-30. 
Chowdhry, B. and Nanda, V., "Stabilization, Syndication, and Pricing of IPOs," Journal of Financial \& Quantitative Analysis, Vol. 31(1), 1996, pp. 25-42.

Chuluun, T., "The Role of Underwriter Peer Networks in IPOs," Journal of Banking and Finance, Vol. 51, 2015, pp. 62-78.

Colaco, H. M. J., Ghosh, C., Knopf, J. D. and Teall, J. L., "IPOs, Clustering, Indirect Learning and Filing Independently," Journal of Banking \& Finance, Vol. 33(11), 2009, pp. 2070-79.

Cook, D. O., Kieschnick, R. and Van Ness, R. A., "On the Marketing of IPOs," Journal of Financial Economics, Vol. 82(1), 2006, pp. 35-61.

Cornelli, F., Goldreich, D. and Ljungqvist, A., “Investor Sentiment and Pre-IPO Markets,” Journal of Finance, Vol. 61(3), 2006, pp. 1187-216.

Da, Z., Engelberg, J. and Gao, P., "The Sum of All FEARS: Investor Sentiment and Asset Prices,” Review of Financial Studies, Vol. 28(1), 2015, pp. 1-32.

Da, Z., Engelberg, J. and Gao, P. J., “In Search of Attention,” Journal of Finance, Vol. 66(5), 2011, pp. 1461-99.

Dambra, M., Field, L. C. and Gustafson, M. T., "The JOBS Act and IPO Volume: Evidence That Disclosure Costs Affect the IPO Decision,” Journal of Financial Economics, Vol. 116, 2015, pp. $121-43$.

Demos, T. and Dembosky, A., "Retail Demand Inflates Facebook IPO Price," Financial Times (FT.com), May 16, 2012.

Demos, T. and Light, J. O. E., “The New Wave of IPOs,” Wall Street Journal - Eastern Edition, 2013. Derrien, F., "IPO Pricing in "Hot" Market Conditions: Who Leaves Money on the Table?” Journal of Finance, Vol. 60(1), 2005, pp. 487-521.

Dimpfl, T. and Jank, S., “Can Internet Search Queries Help to Predict Stock Market Volatility?” European Financial Management, Vol. 22(2), 2016, pp. 171-92.

Dorn, D., "Does Sentiment Drive the Retail Demand for IPOs?" Journal of Financial and Quantitative Analysis, Vol. 44(1), 2009, pp. 85-108. 
Doukas, A. J., Guo, J., Lam, H. Y. T. and Xiao, S., "Media Endorsements of New Product Announcements: A New Marketing Strategy,” European Financial Management, Vol. 22(3), 2016, pp. 394-426.

Drake, M. S., Roulstone, D. T. and Thornock, J. R., "Investor Information Demand: Evidence from Google Searches Around Earnings Announcements," Journal of Accounting Research, Vol. 50, 2012, pp. 1001-40.

Fama, E. F. and French, K. R., "Industry Costs of Equity," Journal of Financial Economics, Vol. 43(2), 1997, pp. 153-93.

Field, L. C. and Karpoff, J. M., “Takeover Defenses of IPO Firms,” Journal of Finance, Vol. 57(5), 2002, pp. 1857-89.

Frieder, L. and Subrahmanyam, A., "Brand Perceptions and the Market for Common Stock," Journal of Financial \& Quantitative Analysis, Vol. 40(1), 2005, pp. 57-85.

Hanley, K. W., "The Underpricing of Initial Public Offerings and the Partial Adjustment Phenomenon,” Journal of Financial Economics, Vol. 34(2), 1993, pp. 231-50.

Hanley, K. W. and Hoberg, G., "The Information Content of IPO Prospectuses,” Review of Financial Studies, Vol. 23(7), 2010, pp. 2821-64.

Herper, M., "Why the JOBS Act Is a Lifesaver for Life Sciences Companies," Forbes.com (Forbes Inc., 2013), pp. 13.

Houston, J., James, C. and Karceski, J., "What a Difference a Month Makes: Stock Analyst Valuations Following Initial Public Offerings,” Journal of Financial and Quantitative Analysis, Vol. 41(1), 2006, pp. 111-37.

Jenkinson, T., Morrison, A. D. and Wilhelm, J. W. J., "Why Are European IPOs so Rarely Priced Outside the Indicative Price Range?” Journal of Financial Economics, Vol. 80(1), 2006, pp. 185-209.

Jeon, J. Q., Lee, C., Nasser, T. and Via, M. T., "Multiple Lead Underwriter IPOs and Firm Visibility," Journal of Corporate Finance, Vol. 32, 2015, pp. 128-49.

Kim, M. and Ritter, J. R., "Valuing IPOs,” Journal of Financial Economics, Vol. 53(3), 1999, pp. 409-37. 
Latham \& Watkins, "The JOBS Act After One Year: A Review of the New IPO Playbook," (Latham \& Watkins LLP, 2013).

Latham \& Watkins, "The Good, the Bad and the Offer: Law, Lore and FAQs," (Latham \& Watkins Capital Markets Practice Group, Client Alert White Paper, 2014).

Liu, J., Nissim, D. and Thomas, J., "Equity Valuation Using Multiples," Journal of Accounting Research, Vol. 40(1), 2002, pp. 135-72.

Liu, L. X., Sherman, A. E. and Zhang, Y., "The Long-Run Role of the Media: Evidence from Initial Public Offerings," Management Science, Vol. 60(8), 2014, pp. 1945-64.

Ljungqvist, A., Nanda, V. and Singh, R., "Hot Markets, Investor Sentiment, and IPO Pricing,” Journal of Business, Vol. 79(4), 2006, pp. 1667-702.

Ljungqvist, A. P. and Wilhelm, W. J., "IPO Allocations: Discriminatory or Discretionary?” Journal of Financial Economics, Vol. 65(2), 2002, pp. 167-201.

Loughran, T. and McDonald, B., "IPO First-Day Returns, Offer Price Revisions, Volatility, and Form S-1 Language,” Journal of Financial Economics, Vol. 109(2), 2013, pp. 307-26.

Loughran, T. and Ritter, J. R., "Why Don't Issuers Get Upset About Leaving Money on the Table in IPOs?" Review of Financial Studies, Vol. 15(2), 2002, pp. 413-43.

Loughran, T. and Ritter, J. R., "Why Has IPO Underpricing Changed over Time?” Financial Management, Vol. 33(3), 2004, pp. 5-37.

Lowry, M. and Schwert, G. W., “Is the IPO Pricing Process Efficient?” Journal of Financial Economics, Vol. 71(1), 2004, pp. 3-26.

Ludvigson, S. C., “Consumer Confidence and Consumer Spending,” The Journal of Economic Perspectives, Vol. 18(2), 2004, pp. 29-50.

McCarthy, E., “Pricing IPOs: Science or Science Fiction?” Journal of Accountancy, Vol. 188(3), 1999, pp. 51-58.

Practical Law, “Testing the Waters Communications and Anchor Investors in IPOs,” 2014 (July 3), available at: http://uk.practicallaw.com/0-572-8590?q=. 
Purnanandam, A. K. and Swaminathan, B., “Are IPOs Really Underpriced?” Review of Financial Studies, Vol. 17(3), 2004, pp. 811-48.

Rueda, A., "The Hot IPO Phenomenon and the Great Internet Bust," Fordham Journal of Corporate \& Financial Law, Vol. 7(1), 2001, pp. 21-100.

Securities and Exchange Commission, "Jumpstart Our Business Startups Act: Frequently Asked Questions About Research Analysts and Underwriters,” 2012 (August 22).

Vozlyublennaia, N., "Investor Attention, Index Performance, and Return Predictability," Journal of Banking and Finance, Vol. 41, 2014, pp. 17-35.

Wang, W. and Yung, C., "IPO Information Aggregation and Underwriter Quality," Review of Finance, Vol. 15(2), 2011, pp. 301-25.

White, H., "A Heteroskedasticity-Consistent Covariance Matrix Estimator and a Direct Test for Heteroskedasticity," Econometrica, Vol. 48(4), 1980, pp. 817-38. 
Table 1

Change in retail investor attention around initial filing

This table presents summary statistics and univariate tests for several measures of percentage changes in retail investor attention around initial IPO filings. The sample includes completed IPOs from 2004-2011 after excluding financial firms (SIC code 6xxx), firms that do not list on NYSE, AMEX, or NASDAQ, and firms that do not have CRSP share codes 10 or 11 . Percentage changes in attention are computed using retail attention either for the week after or the week of the initial filing and retail attention over alternative periods before the initial filing. For example, \% Attention change: Filing $(-1,+1)$ measures the percentage change in retail attention between the week after and the week before the initial filing. The measures of percentage changes in retail investor attention are defined in Appendix A. In Panel A, summary statistics for the percentage changes in retail investor attention are provided. Panel B reports tests of differences in mean values of such percentage changes.

\begin{tabular}{|c|c|c|c|c|c|c|c|c|c|}
\hline & Attention measure & $\mathrm{N}$ & Mean & Std. Dev. & Min & $\mathrm{p} 25$ & Median & p75 & Max \\
\hline (1) & $\%$ Attention change: Filing $(-1,+1)$ & 186 & 27.78 & 47.28 & -36.17 & -3.13 & 16.1 & 46.67 & 142.11 \\
\hline (2) & $\%$ Attention change: Filing $(-2,+1)$ & 187 & 25.88 & 43.01 & -33.33 & -2.63 & 16.67 & 45.45 & 126.42 \\
\hline (3) & $\%$ Attention change: Filing $(-3,+1)$ & 188 & 27.15 & 45.64 & -33.59 & -1.21 & 14.66 & 42.32 & 146.58 \\
\hline (4) & $\%$ Attention change: Filing $(-4,+1)$ & 188 & 26.84 & 41.75 & -29.41 & -0.91 & 16.17 & 45.1 & 119.05 \\
\hline (5) & $\%$ Attention change: Filing $(-1,0)$ & 186 & 30.07 & 42.99 & -25.77 & 0 & 19.16 & 44.44 & 138.1 \\
\hline (6) & $\%$ Attention change: Filing $(-2,0)$ & 187 & 27.71 & 39.12 & -29.17 & 0 & 17.53 & 50.94 & 116.67 \\
\hline (7) & $\%$ Attention change: Filing $(-3,0)$ & 188 & 28.19 & 39.75 & -30.08 & 0 & 20 & 52.47 & 119.23 \\
\hline (8) & $\%$ Attention change: Filing $(-4,0)$ & 188 & 30.41 & 43.56 & -29.14 & 0 & 19.33 & 51.26 & 139.18 \\
\hline
\end{tabular}

Panel B: Comparison of retail investor attention measures

\begin{tabular}{lcccc} 
& $\mathrm{N}$ & Mean (1st measure) & Mean (2nd measure) & paired t-test (p-value) \\
\hline (1) vs. (5) & 186 & 27.78 & 30.07 & 27.71 \\
(2) vs. (6) & 187 & 25.88 & 28.19 & 0.476 \\
(3) vs. (7) & 188 & 27.15 & 30.41 & 0.743 \\
(4) vs. (8) & 188 & 26.84 & & 0.258 \\
\hline
\end{tabular}


Table 2

Summary statistics

This table presents summary statistics for valuation measures and the control variables of the regression models. The sample includes completed IPOs from 2004-2011 after excluding financial firms (SIC code 6xxx), firms that do not list on NYSE, AMEX, or NASDAQ, and firms that do not have CRSP share codes 10 or 11. Valuation measures are built as ratios of a valuation multiple for the IPO (Price-to-Sales, Price-to-Assets or Price-to-EBITDA) to the same multiple for a suitable matching seasoned firm. The control variables should affect IPO valuation and capture the number of news articles between filing and pricing (Media: filing to pricing ) scaled by the number of days (Days) over this period, the change in consumer sentiment (Change in $U M C S$ ), the rank of the underwriter (Underwriter rank), the backing of venture capitalists (Venture capital), the size (Assets and Sales) and age (Age) of the firm, the fraction of shares retained by pre-IPO shareholders (Overhang), the value of growth opportunities ( $P V G O$ Index), the stock exchange on which the IPO is listed (NYSE and NASDAQ), and the stock market performance before the initial pricing (Market return: 90 days before pricing). Variables are defined in Appendix B. Panel A provides summary statistics for valuation measures. Summary statistics for control variables can be found in Panel B.

\begin{tabular}{lcccccccc} 
Panel A: Valuation measures & N & Mean & Std. Dev. & Min & p25 & Median & p75 & Max \\
\hline Price-to-Sales & 546 & 3.89 & 4.69 & 0.25 & 0.79 & 1.85 & 4.77 & 17.46 \\
Price-to-Assets & 546 & 4.86 & 6.72 & 0.28 & 0.83 & 2.21 & 5.9 & 27.3 \\
Price-to-EBITDA & 359 & 2.89 & 4.14 & 0.23 & 0.61 & 1.18 & 2.92 & 16.37 \\
\hline
\end{tabular}

Panel B: Other variables

\begin{tabular}{lcccccccc}
\hline & $\mathrm{N}$ & Mean & Std. Dev. & Min & p25 & Median & p75 & Max \\
\hline Days & 546 & 119.89 & 107.39 & 14 & 65 & 82 & 127 & 795 \\
Media: filing to pricing & 546 & 0.75 & 1.14 & 0.01 & 0.13 & 0.31 & 0.75 & 4.63 \\
Change in UMCS & 546 & 0 & 0.06 & -0.14 & -0.03 & -0.01 & 0.04 & 0.14 \\
Underwriter rank & 546 & 8.11 & 1.25 & 1 & 8 & 8.5 & 9 & 9 \\
Venture capital & 546 & 0.47 & 0.5 & 0 & 0 & 0 & 1 & 1 \\
Assets & 546 & 345.22 & 560.34 & 12.13 & 31.39 & 87.14 & 367.44 & 2169.9 \\
Sales & 546 & 283.81 & 443.93 & 1.09 & 28.99 & 85.24 & 274.75 & 1630.61 \\
Overhang & 546 & 2.96 & 1.5 & 0 & 1.9 & 2.67 & 3.69 & 6.7 \\
Age & 546 & 20.13 & 22.1 & 0 & 7 & 11 & 23 & 88 \\
PVGO index & 546 & 0.73 & 0.36 & 0 & 0.54 & 0.98 & 1 & 1 \\
NYSE & 546 & 0.32 & 0.47 & 0 & 0 & 0 & 1 \\
NASDAQ & 546 & 0.67 & 0.47 & 0 & 0 & 1 & 1 \\
Market return: 90 days before pricing & 546 & 0.06 & 0.08 & -0.06 & 0 & 0.05 & 0.13 & 0.23 \\
\hline
\end{tabular}


Table 3

Univariate tests of relationship between retail investor attention and IPO valuation

This table presents univariate tests of the relationship between retail investor attention and IPO valuation. The sample includes completed IPOs from 2004-2011 after excluding financial firms (SIC code 6xxx), firms that do not list on NYSE, AMEX, or NASDAQ, and firms that do not have CRSP share codes 10 or 11. Valuation measures are built as ratios of a valuation multiple for the IPO (Price-to-Sales, Price-to-Assets or Price-to-EBITDA) to the same multiple for a suitable matching seasoned firm. Attention measures are dummy variables that capture the presence or otherwise of retail investor attention after (Attention dummy: Filing $(+1)$ ) and before (Attention dummy: Filing(-4)) the initial filing date and positive (Increased Attention dummy: Filing $(-4,+1)$ ) or non-positive $($ No Increased Attention dummy: Filing $(-4,+1)$ ) changes in attention following this date. Attention variables are defined in Appendix A. Valuation variables are defined in Appendix B. Panel A presents Pearson correlations between attention and valuation measures. In Panel B, the mean values and distributions of valuation measures for firms with positive SVI values around the filing date (Attention dummy: Filing $(t)=1)$ are compared with those for firms with zero SVI values (Attention dummy: Filing $(t)=0$ ). Attention $\%$ reflects the percentage of firms with attention (i.e., Attention dummy: Filing $(t)=1$ ). In Panel C, the mean values and distributions of valuation measures for firms with positive changes in SVI around the filing date (Increased Attention dummy: Filing $(-4,+1)=1)$ are compared with those for firms with non-positive changes in SVI (No Increased Attention dummy: Filing $(-4,+1)=1$ ). Increased Attention \% reflects the percentage of firms with positive changes in attention (i.e., Increased Attention dummy: Filing $(-4,+1)=1)$ * indicates significance at the 5\% level. Panel A: Pearson correlations

\begin{tabular}{|c|c|c|c|c|c|}
\hline & & $(1)$ & $(2)$ & (3) & (4) \\
\hline (1) & Attention dummy: Filing(+1) & 1 & & & \\
\hline (2) & Attention dummy: Filing(-4) & $0.921^{*}$ & 1 & & \\
\hline (3) & Increased Attention dummy: Filing $(-4,+1)$ & $0.82 *$ & $0.724 *$ & 1 & \\
\hline (4) & No Increased Attention dummy: Filing $(-4,+1)$ & $0.365^{*}$ & $0.448 *$ & $-0.201 *$ & 1 \\
\hline (5) & Price-to-Sales & $0.201 *$ & $0.162 *$ & $0.225^{*}$ & -0.022 \\
\hline (6) & Price-to-Assets & $0.164 *$ & $0.148 *$ & $0.185^{*}$ & -0.027 \\
\hline (7) & Price-to-EBITDA & $0.152 *$ & $0.132 *$ & $0.167 *$ & -0.016 \\
\hline
\end{tabular}

Panel B: Attention and No Attention

\begin{tabular}{|c|c|c|c|c|c|c|c|c|c|c|}
\hline & \multirow[b]{2}{*}{ Filing $(\mathrm{t})$} & \multicolumn{3}{|c|}{ Attention dummy: Filing $(\mathrm{t})=1$} & \multicolumn{3}{|c|}{ Attention dummy: Filing $(\mathrm{t})=0$} & \multicolumn{2}{|c|}{ p-values } & \multirow[b]{2}{*}{ Attention \% } \\
\hline & & $\mathrm{N}$ & Mean & Median & $\mathrm{N}$ & Mean & Median & t-test & Rank sum test & \\
\hline \multirow[t]{2}{*}{ Price-to-Sales } & Filing (+1) & 198 & 5.14 & 2.61 & 348 & 3.17 & 1.63 & $<0.0001$ & $<0.0001$ & $36 \%$ \\
\hline & Filing (-4) & 188 & 4.93 & 2.46 & 358 & 3.34 & 1.69 & 0.0004 & 0.0006 & $34 \%$ \\
\hline \multirow{2}{*}{ Price-to-Assets } & Filing $(+1)$ & 198 & 6.32 & 3.24 & 348 & 4.03 & 1.67 & 0.0003 & $<0.0001$ & $36 \%$ \\
\hline & Filing (-4) & 188 & 6.23 & 3 & 358 & 4.14 & 1.73 & 0.0014 & 0.0006 & $34 \%$ \\
\hline \multirow[t]{2}{*}{ Price-to-EBITDA } & Filing $(+1)$ & 140 & 3.67 & 1.7 & 219 & 2.39 & 0.99 & 0.0064 & 0.0007 & $39 \%$ \\
\hline & Filing (-4) & 137 & 3.58 & 1.65 & 222 & 2.46 & 0.99 & 0.0173 & 0.0027 & $38 \%$ \\
\hline
\end{tabular}

Panel C: Increased and No Increased Attention

\begin{tabular}{|c|c|c|c|c|c|c|c|c|c|}
\hline & \multicolumn{3}{|c|}{$\begin{array}{c}\text { Increased Attention dummy: } \\
\text { Filing }(-4,+1)=1 \\
\end{array}$} & \multicolumn{3}{|c|}{$\begin{array}{l}\text { No Increased Attention dummy: } \\
\text { Filing }(-4,+1)=1\end{array}$} & \multicolumn{2}{|c|}{ p-values } & \multirow[b]{2}{*}{ Increased Attention \% } \\
\hline & $\mathrm{N}$ & Mean & Median & $\mathrm{N}$ & Mean & Median & t-test & Rank sum test & \\
\hline Price-to-Sales & 151 & 5.59 & 3.2 & 52 & 3.57 & 1.34 & 0.0094 & 0.0021 & $74 \%$ \\
\hline Price-to-Assets & 151 & 6.87 & 3.92 & 52 & 4.3 & 1.62 & 0.0213 & 0.0023 & $74 \%$ \\
\hline Price-to-EBITDA & 101 & 3.99 & 1.87 & 44 & 2.71 & 1.3 & 0.0912 & 0.0877 & $70 \%$ \\
\hline
\end{tabular}


Table 4

Retail investor attention and IPO characteristics

This table presents comparisons of IPO characteristics of firms with retail investor attention (positive changes in retail investor attention) after the initial filing date with those of firms without attention (with non-positive changes in attention) after the same date. The sample includes completed IPOs from 2004-2011 after excluding financial firms (SIC code 6xxx), firms that do not list on NYSE, AMEX, or NASDAQ, and firms that do not have CRSP share codes 10 or 11. IPO characteristics capture the number of news articles between filing and pricing (Media: filing to pricing), the change in consumer sentiment (Change in UMCS), the rank of the underwriter (Underwriter rank), the backing of venture capitalists (Venture capital), the size (Assets and Sales) and age (Age) of the firm, the fraction of shares retained by pre-IPO shareholders (Overhang), the value of growth opportunities (PVGO Index), the stock exchange on which the IPO is listed (NYSE and $N A S D A Q$ ), and the stock market performance before the initial pricing (Market return: 90 days before pricing). Attention variables are defined in Appendix A. Other variables are defined in Appendix B. In Panel A, the mean values and distributions of IPO characteristics for firms with positive SVI values in the week following the filing date (Attention dummy: Filing $(+1)=1$ ) are compared with those for firms with zero SVI values $($ Attention dummy: Filing $(+1)=0$ ). In Panel B, the mean values and distributions of IPO characteristics for firms with positive changes in SVI around the filing date (Increased Attention dummy: Filing(-4, +1$)=$ 1) are compared with those for firms with non-positive changes in SVI (No Increased Attention dummy: Filing $(-4,+1)=1$ ).

\begin{tabular}{|c|c|c|c|c|c|c|}
\hline & \multicolumn{2}{|c|}{ Attention dummy: Filing $(+1)=1$} & \multicolumn{2}{|c|}{ Attention dummy: Filing $(+1)=0$} & \multicolumn{2}{|c|}{ p-values } \\
\hline & Mean & Median & Mean & Median & t-test & Rank sum test \\
\hline Change in UMCS & 0 & -0.01 & 0 & 0 & 0.8136 & 0.6947 \\
\hline Media: filing to pricing & 1.44 & 0.8 & 0.35 & 0.19 & $<0.0001$ & $<0.0001$ \\
\hline Underwriter rank & 8.41 & 8.67 & 7.94 & 8.50 & $<0.0001$ & 0.0002 \\
\hline Venture capital & 0.52 & 1 & 0.45 & 0 & 0.1337 & 0.1327 \\
\hline Assets & 369.57 & 91.09 & 331.36 & 76.90 & 0.4597 & 0.0522 \\
\hline Sales & 311.99 & 102.71 & 267.78 & 71.47 & 0.2749 & 0.001 \\
\hline Age & 20.07 & 11 & 20.17 & 11 & 0.9592 & 0.3792 \\
\hline PVGO index & 0.68 & 0.89 & 0.77 & 1 & 0.0117 & 0.0231 \\
\hline Overhang & 3.38 & 3.08 & 2.72 & 2.58 & $<0.0001$ & $<0.0001$ \\
\hline NYSE & 0.33 & 0 & 0.31 & 0 & 0.5358 & 0.5327 \\
\hline NASDAQ & 0.67 & 1 & 0.68 & 1 & 0.7841 & 0.7832 \\
\hline Market return: 90 days before pricing & 0.06 & 0.05 & 0.06 & 0.06 & 0.8334 & 0.8357 \\
\hline Observations & 198 & & 348 & & & \\
\hline
\end{tabular}

Panel B: Increased and No Increased Attention

\begin{tabular}{|c|c|c|c|c|c|c|}
\hline & \multicolumn{2}{|c|}{ Increased Attention dummy: Filing $(-4,+1)=1$} & \multicolumn{2}{|c|}{ No Increased Attention dummy: Filing $(-4,+1)=1$} & \multicolumn{2}{|c|}{ p-values } \\
\hline & Mean & Median & Mean & Median & t-test & Rank sum test \\
\hline Change in UMCS & 0 & 0 & 0 & -0.02 & 0.8935 & 0.5925 \\
\hline Media: filing to pricing & 1.37 & 0.71 & 1.57 & 0.96 & 0.392 & 0.4763 \\
\hline Underwriter rank & 8.4 & 8.67 & 8.44 & 8.79 & 0.802 & 0.3282 \\
\hline Venture capital & 0.54 & 1 & 0.44 & 0 & 0.246 & 0.2427 \\
\hline Assets & 320.28 & 88.25 & 498.77 & 119.44 & 0.1161 & 0.2957 \\
\hline Sales & 258.01 & 88.89 & 457.63 & 154.44 & 0.0258 & 0.041 \\
\hline Age & 18.76 & 11 & 25 & 15.5 & 0.0916 & 0.0503 \\
\hline PVGO index & 0.68 & 0.92 & 0.69 & 0.83 & 0.851 & 0.9863 \\
\hline Overhang & 3.53 & 3.22 & 2.83 & 2.56 & 0.0089 & 0.0043 \\
\hline NASDAQ & 0.71 & 1 & 0.54 & 1 & 0.0343 & 0.0253 \\
\hline Market return: 90 days before pricing & 0.06 & 0.05 & 0.07 & 0.04 & 0.387 & 0.4859 \\
\hline Observations & 151 & & 52 & & & \\
\hline
\end{tabular}


Table 5

OLS regressions of IPO valuation on retail investor attention

This table presents regressions of IPO valuation measures on retail investor attention variables and a set of control variables. The sample includes completed IPOs from 2004-2011 after excluding financial firms (SIC code 6xxx), firms that do not list on NYSE, AMEX, or NASDAQ, and firms that do not have CRSP share codes 10 or 11 . The dependent variables in Panels A and B are Price-to-Sales (Columns 1, 2), Price-to-Assets (Columns 3, 4), and Price-to-EBITDA (Columns 5,6). These valuation measures are built as ratios of a valuation multiple for the IPO to the same multiple for a suitable matching seasoned firm. Attention measures are dummy variables that capture the presence or otherwise of retail investor attention after (Attention dummy: Filing $(+1)$ ) and before (Attention dummy: Filing(-4)) the initial filing date and positive (Increased Attention dummy: Filing $(-4,+1)$ ) or non-positive (No Increased Attention dummy: Filing $(-4,+1)$ ) changes in attention following this date. The control variables should affect IPO valuation and capture the number of news articles between filing and pricing (Ln(Media: filing to pricing)), the change in consumer sentiment (Change in UMCS), the rank of the underwriter (Underwriter rank), the backing of venture capitalists (Venture capital), the size $(\operatorname{Ln}($ Assets $)$ and $\operatorname{Ln}($ Sales $))$ and age $(\operatorname{Ln}(1+$ Age $))$ of the firm, the fraction of shares retained by pre-IPO shareholders (Overhang), the value of growth opportunities ( $P V G O$ Index), the stock exchange on which the IPO is listed (NYSE and NASDAQ), and the stock market performance before the initial pricing (Market return: 90 days before pricing). Attention variables are defined in Appendix A. Other variables are defined in Appendix B. tstatistics of the OLS regressions are in parentheses. Standard errors are adjusted for clustering within the same year based on the pricing date. Asterisks denote statistical significance at the 1\%(***), 5\% (**), or 10\% (*) levels.

Panel A: Attention

(1)

Attention dummy: Filing(+1)

Attention dummy: Filing(-4)

Ln(Assets)

$\operatorname{Ln}$ (Sales)

Change in UMCS

$\operatorname{Ln}$ (Media: filing to pricing)

Underwriter rank

Venture capital

$\operatorname{Ln}(1+$ Age $)$

PVGO index

Overhang

NYSE

NASDAQ

Market return: 90 days before pricing

Constant

Observations

R-squared

Year dummies

Industry dummies

(2)

(3)

(4)

(5)

(6)

\section{$1.499 * * *$ \\ (3.484)}

$-0.892 * *$

$(-3.808)$

$-1.462$

$(-0.511)$

$-0.054$

$(-0.329)$

$0.304 * *$

(2.286)

0.189

(0.242)

$-0.756 * * *$

(-4.187)

$2.278 * * *$

(3.487)

$0.418 * * *$

(3.646)

$1.777 * *$

(1.999)

1.219

(1.31)

$-7.205$

$(-1.327)$

2.5

(0.802)

546

0.327

YES

YES
$1.677 * * *$

(2.956)

0.721

(1.369)

$-0.93 * * *$

(-3.996)

$-1.364$

$$
-1.364
$$

(-0.489)

0.091

(0.525)

$0.307 * *$

(2.356)

0.179

(0.229)

$-0.744 * * *$

$(-4.205)$

$2.175 * * *$

(3.288)

$0.434 * * *$

(3.736)

1.854*

(1.836)

1.325

(1.209)

$-7.276$

(-1.336)

3.671

(1.121)

\section{6}

0.318

YES

YES
$-0.425^{* *}$

(-2.081)

1.867

(0.283)

$-0.337$

$(-1.525)$

$-0.147$

$(-1.258)$

$2.364 * * *$

(3.181)

$-0.79 * *$

$(-2.244)$

$1.711 * * *$

(2.767)

$0.71 * * *$

(3.572)

$-0.889$

$(-0.71)$

$-0.337$

$(-0.427)$

$-8.237$

$(-1.249)$

1.439

(0.472)

546
0.279
YES
YES

(2.084)

$-0.432 * *$

$(-2.125)$

1.951

(0.295)

$-0.228$

(-1.014)

$-0.151$

$(-1.353)$

$2.374 * * *$

(3.15)

$-0.787 * *$

(-2.196)

$1.628 * * *$

(2.608)

$0.718 * * *$

(3.572)

$-0.835$

(-0.689)

$-0.23$

(-0.287)

$-8.402$

$(-1.275)$

2.348

(0.821)

546

0.275

YES

YES
$0.991 * *$

(1.981)

$\begin{array}{cc} & 0.748 \\ & (1.463) \\ -0.737 * * * & -0.757 * * * \\ (-2.95) & (-2.987)\end{array}$

$-2.881$

(-0.584)

$-2.934$

(-0.604)

$-0.023 \quad 0.027$

$(-0.134) \quad(0.163)$

$-0.024 \quad-0.033$

$(-0.116) \quad(-0.165)$

$-0.423 \quad-0.438$

$(-0.472) \quad(-0.487)$

$-0.854 * * * \quad-0.847 * * *$

$(-3.358) \quad(-3.228)$

$2.392 * * * \quad 2.341 * * *$

(3.814) (3.726)

$0.334 * * \quad 0.336 * *$

(2.005) (2.007)

$\begin{array}{ll}-0.000 \quad 0.008 \\ (-0.000) & (0.015)\end{array}$

$(-0.000) \quad(0.015)$

$-6.196$

$(-1.032)$

$7.184 * *$

$-6.404$

$(-1.061)$

$7.752 * *$

(2.407)

(2.149)

359

0.300

YES

YES 
Panel B: Increased attention

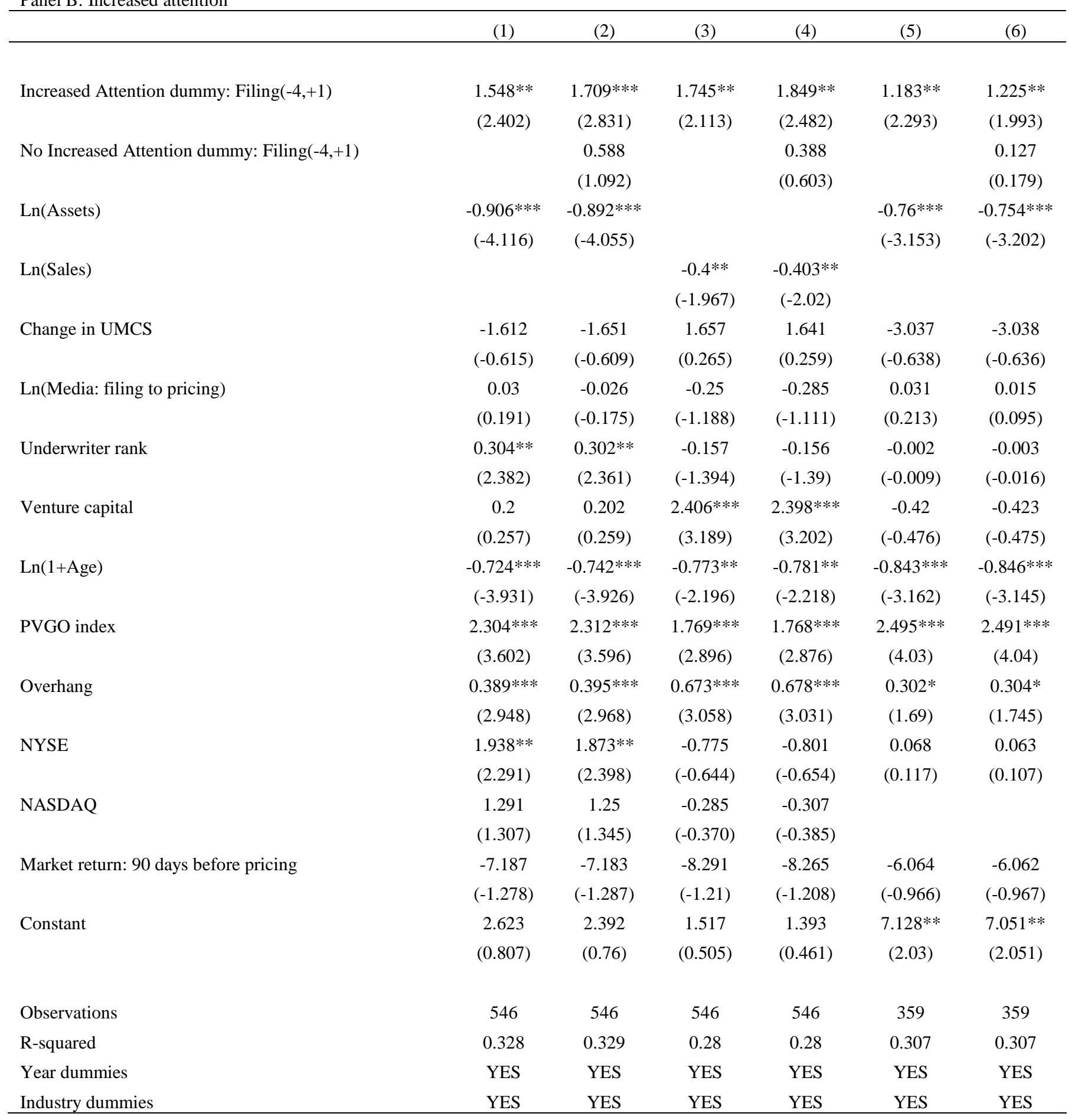


Table 6

OLS regressions of IPO valuation on retail investor attention, controlling for institutional demand

This table presents regressions of IPO valuation measures on retail investor attention variables and a set of control variables. The sample includes completed IPOs from 2004-2011 after excluding financial firms (SIC code 6xxx), firms that do not list on NYSE, AMEX, or NASDAQ, and firms that do not have CRSP share codes 10 or 11. The dependent variables in Panels A-B are Price-to-Sales (Columns 1, 2), Price-to-Assets (Columns 3, 4), and Price-to-EBITDA (Columns 5, 6). Valuation measures are built as ratios of a valuation multiple for the IPO to the same multiple for a suitable matching seasoned firm. Attention measures are dummy variables that capture the presence or otherwise of retail investor attention after (Attention dummy: Filing $(+1))$ and before $($ Attention dummy: Filing $(-4))$ the initial filing date and positive (Increased Attention dummy: Filing $(-4,+1)$ ) or non-positive (No Increased Attention dummy: Filing $(-4,+1)$ ) changes in attention following this date. The control variables reported in the table should reflect institutional demand and capture the number of news articles before the initial filing date (Ln(Media: month before filing)), the IPO price revision (Price update), the number of (Number of institutional investors) and the ownership of institutional investors (Institutional ownership). The control variables from Table 5 are included in the regressions but omitted from the table. Attention variables are defined in Appendix A. Other variables are defined in Appendix B. t-statistics of the OLS regressions are in parentheses. Standard errors are adjusted for clustering within the same year based on the pricing date. Asterisks denote statistical significance at the $1 \%(* * *), 5 \%(* *)$, or $10 \%(*)$ levels.

Panel A: Attention

\begin{tabular}{|c|c|c|c|c|c|c|}
\hline & $(1)$ & $(2)$ & (3) & $(4)$ & $(5)$ & $(6)$ \\
\hline Attention dummy: Filing $(+1)$ & $\begin{array}{c}1.454 * * * \\
(2.851)\end{array}$ & & $\begin{array}{c}1.814 * * \\
(2.544)\end{array}$ & & $\begin{array}{l}1.242 * \\
(1.72)\end{array}$ & \\
\hline Attention dummy: Filing(-4) & & $\begin{array}{c}0.693 \\
(1.098)\end{array}$ & & $\begin{array}{l}1.267 * \\
(1.704)\end{array}$ & & $\begin{array}{c}1.005 \\
(1.329)\end{array}$ \\
\hline Ln(Media: month before filing) & $\begin{array}{c}0.361 \\
(1.311)\end{array}$ & $\begin{array}{c}0.426 \\
(1.508)\end{array}$ & $\begin{array}{c}0.193 \\
(0.485)\end{array}$ & $\begin{array}{c}0.241 \\
(0.606)\end{array}$ & $\begin{array}{c}-0.145 \\
(-0.424)\end{array}$ & $\begin{array}{c}-0.137 \\
(-0.404)\end{array}$ \\
\hline Price update & $\begin{array}{c}-0.011 \\
(-0.663)\end{array}$ & $\begin{array}{c}-0.01 \\
(-0.616)\end{array}$ & $\begin{array}{c}0.022 \\
(1.035)\end{array}$ & $\begin{array}{c}0.022 \\
(1.065)\end{array}$ & $\begin{array}{c}-0.009 \\
(-0.629)\end{array}$ & $\begin{array}{c}-0.009 \\
(-0.609)\end{array}$ \\
\hline Number of institutional investors & $\begin{array}{c}0.033 * * * \\
(3.274)\end{array}$ & $\begin{array}{c}0.034 * * * \\
(3.404)\end{array}$ & $\begin{array}{c}0.021 \\
(1.075)\end{array}$ & $\begin{array}{c}0.022 \\
(1.076)\end{array}$ & $\begin{array}{c}0.013 \\
(1.293)\end{array}$ & $\begin{array}{c}0.014 \\
(1.397)\end{array}$ \\
\hline Institutional ownership & $\begin{array}{c}-0.423 \\
(-0.319)\end{array}$ & $\begin{array}{c}-0.603 \\
(-0.468)\end{array}$ & $\begin{array}{c}-0.098 \\
(-0.056)\end{array}$ & $\begin{array}{c}-0.264 \\
(-0.152)\end{array}$ & $\begin{array}{c}0.196 \\
(0.105)\end{array}$ & $\begin{array}{c}0.06 \\
(0.034)\end{array}$ \\
\hline Constant & $\begin{array}{l}1.281 \\
(0.56)\end{array}$ & $\begin{array}{c}2.341 \\
(1.003)\end{array}$ & $\begin{array}{c}-0.18 \\
(-0.072)\end{array}$ & $\begin{array}{c}0.651 \\
(0.277)\end{array}$ & $\begin{array}{c}9.333 * * \\
(2.255)\end{array}$ & $\begin{array}{c}9.891 * * \\
(2.479)\end{array}$ \\
\hline Observations & 530 & 530 & 530 & 530 & 348 & 348 \\
\hline R-squared & 0.333 & 0.325 & 0.278 & 0.273 & 0.306 & 0.302 \\
\hline Other controls & YES & YES & YES & YES & YES & YES \\
\hline Year dummies & YES & YES & YES & YES & YES & YES \\
\hline Industry dummies & YES & YES & YES & YES & YES & YES \\
\hline
\end{tabular}

Panel B: Increased Attention

\begin{tabular}{|c|c|c|c|c|c|c|}
\hline & $(1)$ & $(2)$ & (3) & $(4)$ & $(5)$ & $(6)$ \\
\hline Increased Attention dummy: Filing $(-4,+1)$ & $\begin{array}{l}1.437 * * \\
(2.095)\end{array}$ & $\begin{array}{l}1.635 * * \\
(2.505)\end{array}$ & $\begin{array}{c}1.492 * \\
(1.824)\end{array}$ & $\begin{array}{c}1.802 * * \\
(2.161)\end{array}$ & $\begin{array}{l}1.335^{* *} \\
(2.375)\end{array}$ & $\begin{array}{c}1.457^{*} \\
(1.855)\end{array}$ \\
\hline No Increased Attention dummy: Filing $(-4,+1)$ & & $\begin{array}{c}0.715 \\
(1.116)\end{array}$ & & $\begin{array}{c}1.141 \\
(1.359)\end{array}$ & & $\begin{array}{c}0.364 \\
(0.358)\end{array}$ \\
\hline Ln(Media: month before filing) & $\begin{array}{c}0.388 \\
(1.411)\end{array}$ & $\begin{array}{l}0.356 \\
(1.32)\end{array}$ & $\begin{array}{c}0.247 \\
(0.641)\end{array}$ & $\begin{array}{l}0.197 \\
(0.49)\end{array}$ & $\begin{array}{c}-0.14 \\
(-0.432)\end{array}$ & $\begin{array}{c}-0.155 \\
(-0.461)\end{array}$ \\
\hline Price update & $\begin{array}{c}-0.013 \\
(-0.777)\end{array}$ & $\begin{array}{c}-0.012 \\
(-0.737)\end{array}$ & $\begin{array}{c}0.02 \\
(0.968)\end{array}$ & $\begin{array}{c}0.021 \\
(0.999)\end{array}$ & $\begin{array}{c}-0.012 \\
(-0.865)\end{array}$ & $\begin{array}{c}-0.012 \\
(-0.784)\end{array}$ \\
\hline Number of institutional investors & $\begin{array}{c}0.033 * * * \\
(3.414)\end{array}$ & $\begin{array}{c}0.033 * * * \\
(3.346)\end{array}$ & $\begin{array}{c}0.021 \\
(1.043)\end{array}$ & $\begin{array}{c}0.021 \\
(1.054)\end{array}$ & $\begin{array}{c}0.013 \\
(1.234)\end{array}$ & $\begin{array}{c}0.013 \\
(1.263)\end{array}$ \\
\hline Institutional ownership & $\begin{array}{c}-0.606 \\
(-0.495)\end{array}$ & $\begin{array}{c}-0.516 \\
(-0.396)\end{array}$ & $\begin{array}{c}-0.359 \\
(-0.207)\end{array}$ & $\begin{array}{c}-0.207 \\
(-0.119)\end{array}$ & $\begin{array}{c}-0.015 \\
(-0.009)\end{array}$ & $\begin{array}{c}0.062 \\
(0.034)\end{array}$ \\
\hline Constant & $\begin{array}{c}1.466 \\
(0.616)\end{array}$ & $\begin{array}{c}1.204 \\
(0.525)\end{array}$ & $\begin{array}{c}0.332 \\
(0.142)\end{array}$ & $\begin{array}{c}-0.022 \\
(-0.009)\end{array}$ & $\begin{array}{l}9.84 * * \\
(2.331)\end{array}$ & $\begin{array}{c}9.549 * * \\
(2.3)\end{array}$ \\
\hline Observations & 530 & 530 & 530 & 530 & 348 & 348 \\
\hline R-squared & 0.334 & 0.335 & 0.275 & 0.277 & 0.309 & 0.309 \\
\hline Other controls & YES & YES & YES & YES & YES & YES \\
\hline Year dummies & YES & YES & YES & YES & YES & YES \\
\hline Industry dummies & YES & YES & YES & YES & YES & YES \\
\hline
\end{tabular}


Table 7

OLS regressions of IPO valuation on retail investor attention, controlling for promotional efforts

This table presents regressions of IPO valuation measures on retail investor attention variables and a set of control variables. The sample includes completed IPOs from 2004-2011 after excluding financial firms (SIC code 6xxx), firms that do not list on NYSE, AMEX, or NASDAQ, and firms that do not have CRSP share codes 10 or 11 . The dependent variables in Panels A-B are Price-to-Sales (Columns 1, 2), Price-to-Assets (Columns 3, 4), and Price-to-EBITDA (Columns 5,6). Valuation measures are built as ratios of a valuation multiple for the IPO to the same multiple for a suitable matching seasoned firm. Attention measures are dummy variables that capture the presence or otherwise of retail investor attention after (Attention dummy: Filing $(+1)$ ) and before (Attention dummy: Filing $(-4))$ the initial filing date and positive (Increased Attention dummy: Filing $(-4,+1)$ ) or non-positive (No Increased Attention dummy: Filing $(-4,+1)$ ) changes in attention following this date. The control variables reported in the table should reflect underwriter promotional efforts and capture the number of news articles before the initial filing date (Ln(Media: month before filing)), the presence of multiple lead underwriters $(M L U)$, the number of co-managers (Number of co-managers), and the gross spread (Gross spread). The control variables from Table 5 are included in the regressions but omitted from the table. Attention variables are defined in Appendix A. Other variables are defined in Appendix B. t-statistics of the OLS regressions are in parentheses. Standard errors are adjusted for clustering within the same year based on the pricing date. Asterisks denote statistical significance at the $1 \%(* * *), 5 \%(* *)$, or $10 \%(*)$ levels.

\begin{tabular}{|c|c|c|c|c|c|c|}
\hline & $(1)$ & $(2)$ & (3) & (4) & $(5)$ & $(6)$ \\
\hline Attention dummy: Filing(+1) & $\begin{array}{c}1.375 * * \\
(2.414)\end{array}$ & & $\begin{array}{c}1.685^{* *} \\
(2.328)\end{array}$ & & $\begin{array}{c}1.1^{*} \\
(1.861)\end{array}$ & \\
\hline Attention dummy: Filing(-4) & & $\begin{array}{c}0.638 \\
(1.064)\end{array}$ & & $\begin{array}{c}1.058 \\
(1.639)\end{array}$ & & $\begin{array}{c}0.817 \\
(1.398)\end{array}$ \\
\hline Ln(Media: month before filing) & $\begin{array}{c}0.224 \\
(0.651)\end{array}$ & $\begin{array}{c}0.289 \\
(0.833)\end{array}$ & $\begin{array}{c}0.065 \\
(0.137)\end{array}$ & $\begin{array}{c}0.122 \\
(0.259)\end{array}$ & $\begin{array}{c}-0.264 \\
(-0.614)\end{array}$ & $\begin{array}{c}-0.251 \\
(-0.584)\end{array}$ \\
\hline MLU & $\begin{array}{c}0.101 \\
(0.245)\end{array}$ & $\begin{array}{c}0.15 \\
(0.378)\end{array}$ & $\begin{array}{c}0.323 \\
(0.4)\end{array}$ & $\begin{array}{c}0.361 \\
(0.445)\end{array}$ & $\begin{array}{c}0.55 \\
(1.236)\end{array}$ & $\begin{array}{c}0.571 \\
(1.253)\end{array}$ \\
\hline Number of co-managers & $\begin{array}{l}0.135 \\
(1.27)\end{array}$ & $\begin{array}{c}0.152 \\
(1.515)\end{array}$ & $\begin{array}{c}0.017 \\
(0.078)\end{array}$ & $\begin{array}{c}0.029 \\
(0.131)\end{array}$ & $\begin{array}{c}-0.02 \\
(-0.105)\end{array}$ & $\begin{array}{c}-0.011 \\
(-0.058)\end{array}$ \\
\hline Gross spread & $\begin{array}{c}-0.14 \\
(-0.837)\end{array}$ & $\begin{array}{c}-0.142 \\
(-0.859)\end{array}$ & $\begin{array}{c}-0.223 \\
(-0.494)\end{array}$ & $\begin{array}{c}-0.222 \\
(-0.487)\end{array}$ & $\begin{array}{c}-0.095 \\
(-0.252)\end{array}$ & $\begin{array}{c}-0.113 \\
(-0.292)\end{array}$ \\
\hline Constant & $\begin{array}{c}3.786 \\
(0.918)\end{array}$ & $\begin{array}{c}4.909 \\
(1.194)\end{array}$ & $\begin{array}{c}3.26 \\
(0.617)\end{array}$ & $\begin{array}{c}4.163 \\
(0.801)\end{array}$ & $\begin{array}{c}8.105 \\
(1.489)\end{array}$ & $\begin{array}{l}8.864 * \\
(1.654)\end{array}$ \\
\hline Observations & 540 & 540 & 540 & 540 & 357 & 357 \\
\hline R-squared & 0.327 & 0.319 & 0.280 & 0.276 & 0.307 & 0.304 \\
\hline Other controls & YES & YES & YES & YES & YES & YES \\
\hline Year dummies & YES & YES & YES & YES & YES & YES \\
\hline Industry dummies & YES & YES & YES & YES & YES & YES \\
\hline
\end{tabular}

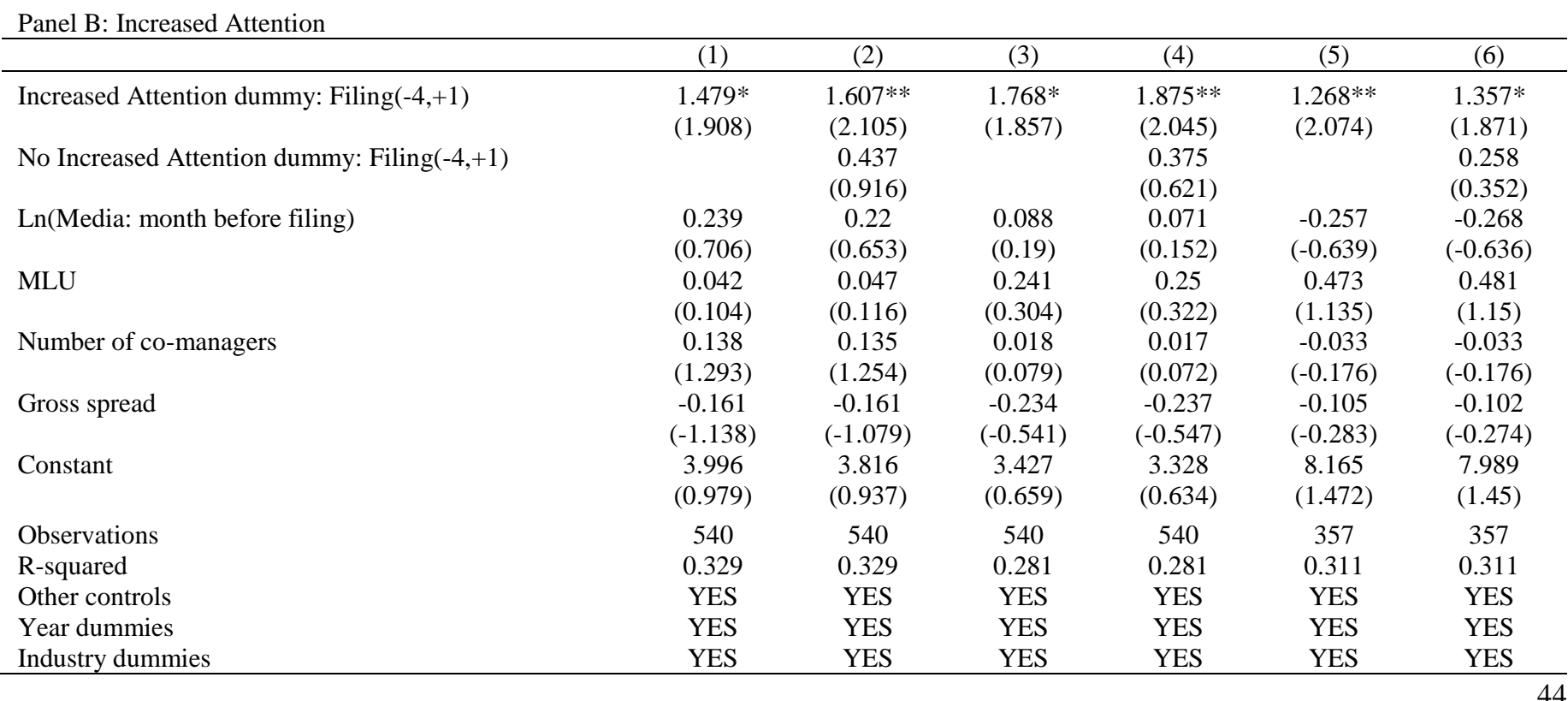


Table 8

OLS regressions of IPO valuation on retail investor attention (continuous attention measure)

This table presents regressions of IPO valuation measures on the percentage change in retail investor attention and a set of control variables. The sample includes completed IPOs from 2004-2011 after excluding financial firms (SIC code 6xxx), firms that do not list on NYSE, AMEX, or NASDAQ, and firms that do not have CRSP share codes 10 or 11. The dependent variables are Price-to-Sales (Column 1), Price-to-Assets (Column 2), and Price-to-EBITDA (Column 3). Valuation measures are built as ratios of a valuation multiple for the IPO (Price-to-Sales, Price-to-Assets or Price-to-EBITDA) to the same multiple for a suitable matching seasoned firm. \% Attention change: Filing $(-4,+1)$ measures the percentage change in retail attention between the week after and the four weeks before the initial filing. The control variables from Table 5 are included in the regressions but omitted from the table. Attention variables are defined in Appendix A. Other variables are defined in Appendix B. t-statistics of the OLS regressions are in parentheses. Standard errors are adjusted for clustering within the same year based on the pricing date. Asterisks denote statistical significance at the $1 \%(* * *), 5 \%(* *)$, or $10 \%(*)$ levels.

\begin{tabular}{lccc}
\hline & $(1)$ & $(2)$ & $(3)$ \\
\hline \% Attention change: Filing(-4,+1) & & & \\
& 0.003 & 0.013 & $0.034^{* * *}$ \\
Constant & $(0.25)$ & $(0.52)$ & $(2.694)$ \\
& 10.22 & 14.84 & $19.2^{* * *}$ \\
& $(1.465)$ & $(1.467)$ & $(3.114)$ \\
Observations & & & 137 \\
R-squared & 188 & 188 & 0.397 \\
Controls & 0.433 & 0.326 & YES \\
Year dummies & YES & YES & YES \\
Industry dummies & YES & YES & YES \\
\hline
\end{tabular}

